Article

\title{
Chaperone-Like Activity of HSPB5: The Effects of Quaternary Structure Dynamics and Crowding
}

\author{
Natalia A. Chebotareva *, Svetlana G. Roman, Vera A. Borzova, Tatiana B. Eronina, \\ Valeriya V. Mikhaylova and Boris I. KurganoviD \\ Bach Institute of Biochemistry, Federal Research Centre "Fundamentals of Biotechnology" of the Russian \\ Academy of Sciences, Leninsky pr. 33, 119071 Moscow, Russia; svetabaj@gmail.com (S.G.R.); \\ squsiebox@gmail.com (V.A.B.); eronina@inbi.ras.ru (T.B.E.); mikhaylova.inbi@inbox.ru (V.V.M.); \\ boris@kurganov.com (B.I.K.) \\ * Correspondence: n.a.chebotareva@gmail.com
}

Received: 8 June 2020; Accepted: 10 July 2020; Published: 13 July 2020

\begin{abstract}
Small heat-shock proteins (sHSPs) are ATP-independent molecular chaperones that interact with partially unfolded proteins, preventing their aberrant aggregation, thereby exhibiting a chaperone-like activity. Dynamics of the quaternary structure plays an important role in the chaperone-like activity of sHSPs. However, relationship between the dynamic structure of sHSPs and their chaperone-like activity remains insufficiently characterized. Many factors (temperature, ions, a target protein, crowding etc.) affect the structure and activity of sHSPs. The least studied is an effect of crowding on sHSPs activity. In this work the chaperone-like activity of HSPB5 was quantitatively characterized by dynamic light scattering using two test systems, namely test systems based on heat-induced aggregation of muscle glycogen phosphorylase $b(\mathrm{Ph} b)$ at $48^{\circ} \mathrm{C}$ and dithiothreitol-induced aggregation of $\alpha$-lactalbumin at $37^{\circ} \mathrm{C}$. Analytical ultracentrifugation was used to control the oligomeric state of $\mathrm{HSPB} 5$ and target proteins. The possible anti-aggregation functioning of suboligomeric forms of HSPB5 is discussed. The effect of crowding on HSPB5 anti-aggregation activity was characterized using $\mathrm{Ph} b$ as a target protein. The duration of the nucleation stage was shown to decrease with simultaneous increase in the relative rate of aggregation of $\mathrm{Ph} b$ in the presence of HSPB5 under crowded conditions. Crowding may subtly modulate sHSPs activity.
\end{abstract}

Keywords: HSPB5; chaperone-like activity; oligomeric states; mixed crowding

\section{Introduction}

$\alpha \mathrm{B}$-Crystallin belongs to a superfamily of small heat shock proteins (sHSPs), which are ubiquitously expressed and play an important role in maintaining cellular proteostasis [1]. sHSPs bind non-native and misfolded proteins, keeping them from further aggregation and protecting the cell from toxic aggregates [1-5]. In addition to the exhibition of the anti-aggregation (chaperone-like) activity, these proteins are involved in many important processes in the cell, such as apoptosis, stabilization of cytoskeleton [6], regulation of muscle contraction, regulation of redox state [7], signal transduction, etc. [4,8-10]. Given these significant biological roles, the dysregulation of sHSPs is associated with cancer [11], cataract formation [12-14], and neurodegenerative diseases [5,10]. It is known that mutations in sHSPs have been directly linked to different myopathies including Charcot-Marie-Tooth disease and neuropathy $[10,14,15]$. Therefore, the processes of regulation of the functioning of sHSPs are very important.

Among the ten human sHSPs, $\alpha \mathrm{B}$-crystallin (HSPB5) is one of the principle members. HSPB5 is widespread in all tissues, but its concentration in the eye lens is especially high ( $400 \mathrm{mg} / \mathrm{mL}$ ), where it interacts with $\alpha \mathrm{A}$-crystallin (HSPB4) and forms a native hetero-oligomeric complex, $\alpha$-crystallin [16]. 
These proteins ensure the transparency of the eye lens [17], preventing the aggregation of other crystallins and thereby protecting the lens from the development of cataracts [12]. All sHSPs, such as HSPB5, in their structure have a central $\alpha$-crystalline domain (ACD) with an ordered structure, which is flanked by two variable terminal regions, $\mathrm{C}$ - and $\mathrm{N}$ - terminal domains, with a partially disordered structure, intrinsically disordered regions (IDRs) [18]. The ACD domain plays an important role in the formation of a dimer, which is considered as the building block that assembles via terminal interactions into a polydisperse ensemble under physiological conditions $[9,19,20]$. $\mathrm{N}$-terminal regions are involved in the formation of large oligomers [18,21,22]. Carver and coworkers proposed, that the mobile C- and N-terminal regions of HSPB5 are involved in regulation of interaction with substrates; they protect ACD domain from amyloid fibril formation [20] and the flexibility of these regions, especially C-terminal regions, provides solubility for sHSPs $[18,20]$. The importance of the IDRs regions in sHSPs for formation of dynamic macromolecular assemblies and regulation of protein functionality has been discussed in the work [10].

HSPB5 tends to form large polydisperse assemblies ranging from 10-mer to 40-mer and higher, having very dynamic structures [19,23-25]. All oligomeric forms possess chaperone-like activity and easily exchange their subunits $[20,26,27]$. It is well accepted that a flexible dynamic quaternary structure is necessary for sHSPs activity $[1,4,10,28]$. Changes in the cellular environment, such as temperature [9,10,27,29], $\mathrm{pH}[30]$, the presence of ions [31,32], post-translational modification (phosphorylation) [33-35], redox environment [7,30] and crowding [19,25,32,36-38] also regulate chaperone activity by affecting the structural and oligomerization dynamics of sHSPs [4,5]. It has been reported that sHSP dynamics is a very complex process that includes five levels of regulation: (1) flexible domains flanking the ACD, (2) polydisperse self-oligomerization, (3) hetero- oligomerization with other sHSPs, (4) subunit exchange, and (5) regulation by the cellular environment $[5,39]$. As such, multiple oligomeric forms are likely relevant to function, and regulation thereof. The importance of quaternary dynamics for realization of chaperone activity of sHsps was discussed in $[5,9,10,19,28,29]$. However, the relationship between the dynamic variable structure and functions of sHSPs is far from being clear. The least studied is the effect of crowding on this relationship.

The cellular interior contains large concentrations of macromolecules, reaching up to $400 \mathrm{~g} / \mathrm{L}$, including proteins, nucleic acids, lipids, glycans, and solvated ions [40,41]. This means that about $40 \%$ of cell volume may be occupied by macromolecules and become physically unavailable for other molecules. A nonspecific influence of such unavailable volume on the specific biochemical reactions [42,43] was termed macromolecular crowding or excluded volume effect [44]. Theory predicts that crowding affects both the kinetics and thermodynamics of interactions between macromolecules, including protein aggregation [38,42,43,45-48].

It is usual to mimic crowded milieu in vitro by adding high concentration of suitable inert polymer or protein, so-called crowding agent, such as polyethylene glycols (PEG) of different molecular mass, polysaccharides (Ficoll, dextran), polyvinylpyrrolidone (PVP) or proteins (bovine serum albumin, lysozyme) [42]. For a long time, researchers simulated crowding in vitro by adding a single crowding agent at concentrations $>100 \mathrm{mg} / \mathrm{mL}$. Considering that the molecules of crowders are completely neutral and the effect of crowding on biochemical reactions is manifested due to steric repulsion of macromolecules, that is, the excluded volume effect (EVE). Currently, it is believed that the influence of crowding can be considered to be a mixture of entropic (excluded volume) and enthalpy based (soft interactions) effects [47,49-52]. "Soft" interactions include electrostatic, hydrophobic, and van der Waals interactions between the crowding agent and studied protein $[53,54]$. These interactions can be repulsive or attractive. Therefore, such soft interactions (enthalpy factor) can counteract EVE [50,55-58].

Given that in a cell crowding is created by the presence of different molecules that differ in size, shape and charge, some groups of researchers came to the conclusion that it is better to imitate physiological conditions in vitro with a mixture of several crowders (mixed crowding) [47,49-52,59]. It has been shown that two crowders can exhibit a synergistic effect, significantly enhancing the effect of each other, even when using relatively small concentrations $(10-20 \mathrm{mg} / \mathrm{mL})$ [49]. It has also been 
shown that small crowders create more total excluded volume in the vicinity of big crowder than in the bulk $[49,58]$. Sharp pointed out that when the steric effects of macromolecular crowders and small molecules like water and ions are treated on an equal footing, the effect of the macromolecules are less effective at crowding than water and ions [60]. Shah and coworkers developed a molecular thermodynamic formalism to examine the effects of size-polydispersity of crowders on aggregation reaction equilibrium. They showed that in the case of polydisperse crowders, the crowders with the largest size difference dominate the overall changes in the yield of the reaction [50].

Thus, crowding adds another level of complexity to the relationship between the activity and structural dynamics of HSPB5. Since it has a strong effect on protein-protein interactions, it should affect the conformation and self-association of the chaperone, the interaction of the chaperone with the target protein, and the aggregation of the target protein. Previously, we have shown by the analytical ultracentrifugation (AUC) method that crowding strongly affects the oligomeric state of HSPB5, HSPB6, HSPB1 and $\alpha$-crystallin $[25,32,36,61-64]$. Thus, one might assume that crowding affects the capability of sHSPs to prevent aggregation of target proteins.

The goal of this work was to quantitatively assess the effect of crowding, including mixed crowding, on the chaperone-like activity of HSPB5. As the process of protein aggregation includes the stage of protein unfolding followed by the aggregation of unfolded protein molecules, in a general case, sHSPs can affect the unfolding stages as well as the aggregation stage. Therefore, it is very important to question what stage of the overall aggregation process (unfolding or aggregation) is rate-limiting in the selected test system.

In the present work, two test systems were selected to study the chaperone-like activity of HSPB5, one of which is based on the thermal aggregation of glycogen phosphorylase $b(\mathrm{Ph} b)$ at $48^{\circ} \mathrm{C}$, and the other is based on dithiothreitol-induced aggregation of $\alpha$-lactalbumin at $37^{\circ} \mathrm{C}$; these test systems were described earlier [65-68]. Ph $b$ exists as a dimer consisting of two identical subunits with molecular mass of $97.4 \mathrm{kDa}$ each [69]. $\alpha$-Lactalbumin $(\alpha \mathrm{La})$ is a small $\mathrm{Ca}^{2+}$-binding protein containing four disulfide bridges with molar mass of $14.2 \mathrm{kDa}$. Under stress conditions, the $\mathrm{Ca}^{2+}$-depleted form of $\alpha$-lactalbumin attains a classical molten globule state that aggregates amorphously [70-73]. The molten globule conformation of $\alpha$-lactalbumin is thought to be a target for interacting with sHSPs [66,68,70-76]. The rate-limiting stages were established for the aggregation process for both proteins and the effect of HSPB5 on aggregation of these proteins was quantitatively evaluated.

We compared the effect of crowding by both individual crowders and pairs of crowders on the anti-aggregation activity of HSPB5 using $\mathrm{Ph} b$ as a target protein. Four pairs of crowders demonstrated a synergistic effect on the activity of HSPB5. This study has provided insights into the mechanism of chaperone function under crowded conditions.

\section{Results}

\subsection{Protein Aggregation. Theoretical Analysis of the Initial Parts of the Kinetic Curves}

One of the distinctive features of the kinetics of protein aggregation is the existence of the lag phase on the kinetic curves demonstrating enhancing the aggregation rate in the course of accumulation of protein aggregates. The appearance of the lag phase may be an indication of fulfilment of the mechanism termed "nucleation-dependent aggregation". According to this mechanism, the initial stage of the process of protein aggregation is the stage of cooperative association of unfolded protein molecules, which results in the formation of nuclei [77-80]. The initial steps of the sticking of unfolded protein molecules are thermodynamically unfavorable. However, owing to contacts of each protein molecule with several neighbors in larger associates the change in the free energy becomes negative in the course of enlargement of the associate.

Theoretical studies predict that accumulation of the aggregated protein during nucleation stage is proportional to time squared [78]. Chen et al. [81] obtained experimental confirmation of such a regularity. When the kinetics of the protein aggregation is registered by measuring the increment of 
the light scattering intensity $(I)$, the following quadratic equation can be used for a description of the part of the kinetic curve corresponding to the nucleation stage [82-84] (Figure 1A):

$$
I-I_{0}=K_{\mathrm{agg}}\left(t-t_{0}\right)^{2}
$$

where $I_{0}$ is an initial value of the light scattering intensity at $t=0$ and $t_{0}$ is the moment of time at which the initial increment of the light scattering intensity is registered. $K_{\text {agg }}$ is a parameter characterizing the acceleration of the aggregation process during the nucleation stage.
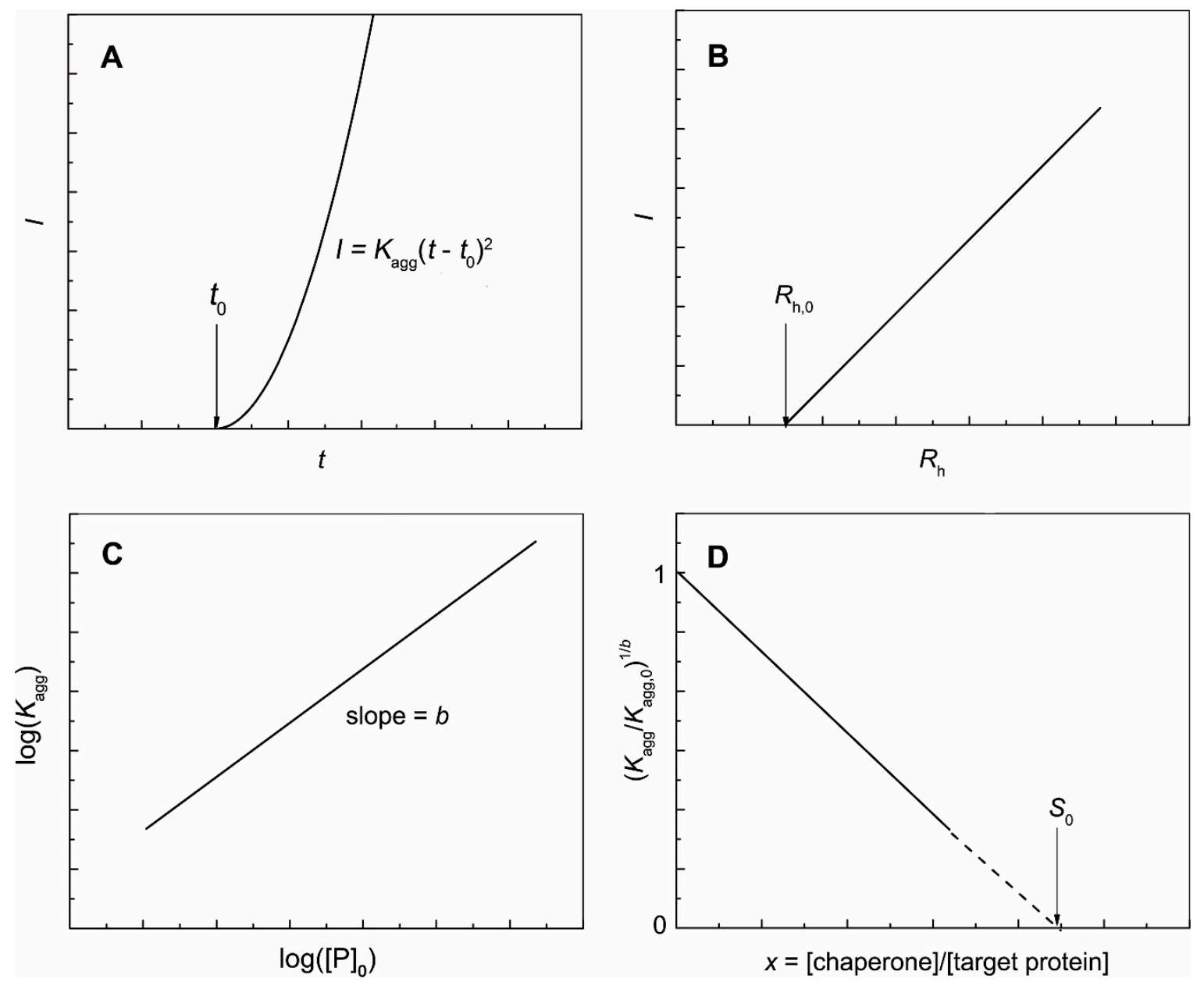

Figure 1. Theoretical analysis of the initial parts of the kinetic curves registered for protein aggregation by measuring the increment of the light scattering intensity. (A) The dependence of the light scattering intensity $(I)$ on time ( $t$ ) obeying Equation (1). (B) The light scattering intensity $(I)$ versus the hydrodynamic radius $\left(R_{\mathrm{h}}\right)$ plot used for calculation of the hydrodynamic radius of start aggregates $\left(R_{\mathrm{h}, 0}\right)$. (C) The $\log \left(K_{\mathrm{agg}}\right)$ versus $\log \left([\mathrm{P}]_{0}\right)$ plot used for calculation of the parameter $b$. (D) The $\left(K_{\mathrm{agg}} / K_{\mathrm{agg}, 0}\right)^{1 / b}$ versus $x=$ [chaperone]/[target protein] plot used for calculation of the stoichiometry of the chaperone-target protein complex $\left(S_{0}\right)$.

The nuclei appeared at $t=t_{0}$ were called start aggregates [85]. To determine the hydrodynamic radius of start aggregates $\left(R_{\mathrm{h}, 0}\right)$, a plot of $I$ versus $R_{\mathrm{h}}$ can be constructed [86,87] (Figure 1B).

The determination of the parameter $K_{\text {agg }}$ value at different initial protein concentrations, $[\mathrm{P}]_{0}$, allows calculating the order of aggregation with respect to the protein (b) [84] (Figure 1C):

$$
K_{\mathrm{agg}}=\mathrm{const}[\mathrm{P}]_{0}^{b}
$$


To quantitate the anti-aggregation activity of a chaperone that form a tight complex with their targets, we used a parameter characterizing the initial adsorption capacity of the chaperone $\left(A C_{0}\right)[83,84,88,89]$. To determine $A C_{0}$, we need to analyze the dependence of the $\left(K_{\mathrm{agg}} / K_{\mathrm{agg}, 0}\right)^{1 / b}$ ratio ( $K_{\mathrm{agg}, 0}$ is the value of parameter $K_{\mathrm{agg}}$ in the absence of the chaperone) on the ratio of molar concentrations of the chaperone and a target protein $(x=$ [chaperone]/[target protein]). The stoichiometry of the chaperone-target protein complex $\left(S_{0}\right)$ can be determined as a length on the abscissa axis cut off by the linear part of the dependence of $\left(K_{\mathrm{agg}} / K_{\mathrm{agg}, 0}\right)^{1 / b}$ on $x$ (Figure 1D):

$$
\left(K_{\mathrm{agg}} / K_{\mathrm{agg}, 0}\right)^{1 / b}=1-x / S_{0}=1-A C_{0} x
$$

The $A C_{0}$ value can be calculated as a reciprocal to the $S_{0}$ :

$$
A C_{0}=1 / S_{0}
$$

In this work, we selected the parameter $K_{\text {agg }}$ with the aim (1) to characterize the effect of the chaperone on the aggregation kinetics using two model substrates, namely $\mathrm{Ph} b$ (for testing thermal aggregation) and $\alpha \mathrm{La}$ (for testing DTT-induced aggregation) and (2) to quantitatively assess the effect of crowding on the chaperone-like activity of HSPB5.

\subsection{The Effect of HSPB5 on Thermal Aggregation of Phb}

Figure 2A shows the kinetic curves of thermal aggregation of $\mathrm{Ph} b$ at $48{ }^{\circ} \mathrm{C}(0.03 \mathrm{M}$ Hepes buffer, $0.1 \mathrm{M} \mathrm{NaCl}, 0.2 \mathrm{mM}$ EDTA, $\mathrm{pH}$ 6.8) registered by measuring the increment of the light scattering intensity $(I)$ at several protein concentrations. The initial parts of the kinetic curves can be approximated by the quadratic Equation (1). As it can be seen from Figure 2B, there is no change in the $t_{0}$ value at varying $\mathrm{Ph} b$ concentration. The average value of $t_{0}$ measured at $\mathrm{Ph} b$ concentrations ranging from 0.1 to $0.9 \mathrm{mg} / \mathrm{mL}$ was found to be $136 \pm 4 \mathrm{~s}$. The dependence of $K_{\mathrm{agg}}$ on Phb concentration is linear (Figure 2C), i.e., the coefficient $b$ in Equation (2) is equal to unity. This means that the unfolding of the $\mathrm{Ph} b$ molecule proceeds with a substantially lower rate than the subsequent stages of aggregation of unfolded protein molecules. Thus, we may use the linear calibration curve $\left\{K_{\mathrm{agg}} ;[\mathrm{Ph} b]_{0}\right\}$ for estimating the effect of different agents (namely HSPB5 in the present work) on the initial stages of thermal aggregation of the protein.

When aggregation of $\mathrm{Ph} b$ at $48^{\circ} \mathrm{C}$ was monitored in the presence of HSPB5, the retardation of the aggregation process was observed. Figure $3 \mathrm{~A}$ demonstrates the initial parts of the dependences of the light scattering intensity on time obtained at several concentrations of $\mathrm{Ph} b$ in the presence of HSPB5 at the concentration of $0.025 \mathrm{mg} / \mathrm{mL}$. Parameters $t_{0}$ and $K_{\mathrm{agg}}$ for these dependences were estimated using Equation (1).

The $t_{0}$ value is not markedly changed in the range of $\mathrm{Ph} b$ concentrations from 0.15 to $0.6 \mathrm{mg} / \mathrm{mL}$, being approximately $280 \mathrm{~s}$, and slightly decreases to $218 \mathrm{~s}$ at $[\mathrm{Ph} b]=0.75 \mathrm{mg} / \mathrm{mL}$ (Figure 3B). Just like in the case of $\mathrm{Ph} b$ aggregation in the absence of the chaperone, the dependence of the parameter $K_{\mathrm{agg}}$ on $[\mathrm{Ph} b]$ appeared to be linear in the presence of HSPB5 (Figure 3C) yet the slope of the line decreased by a factor of 3.5. 

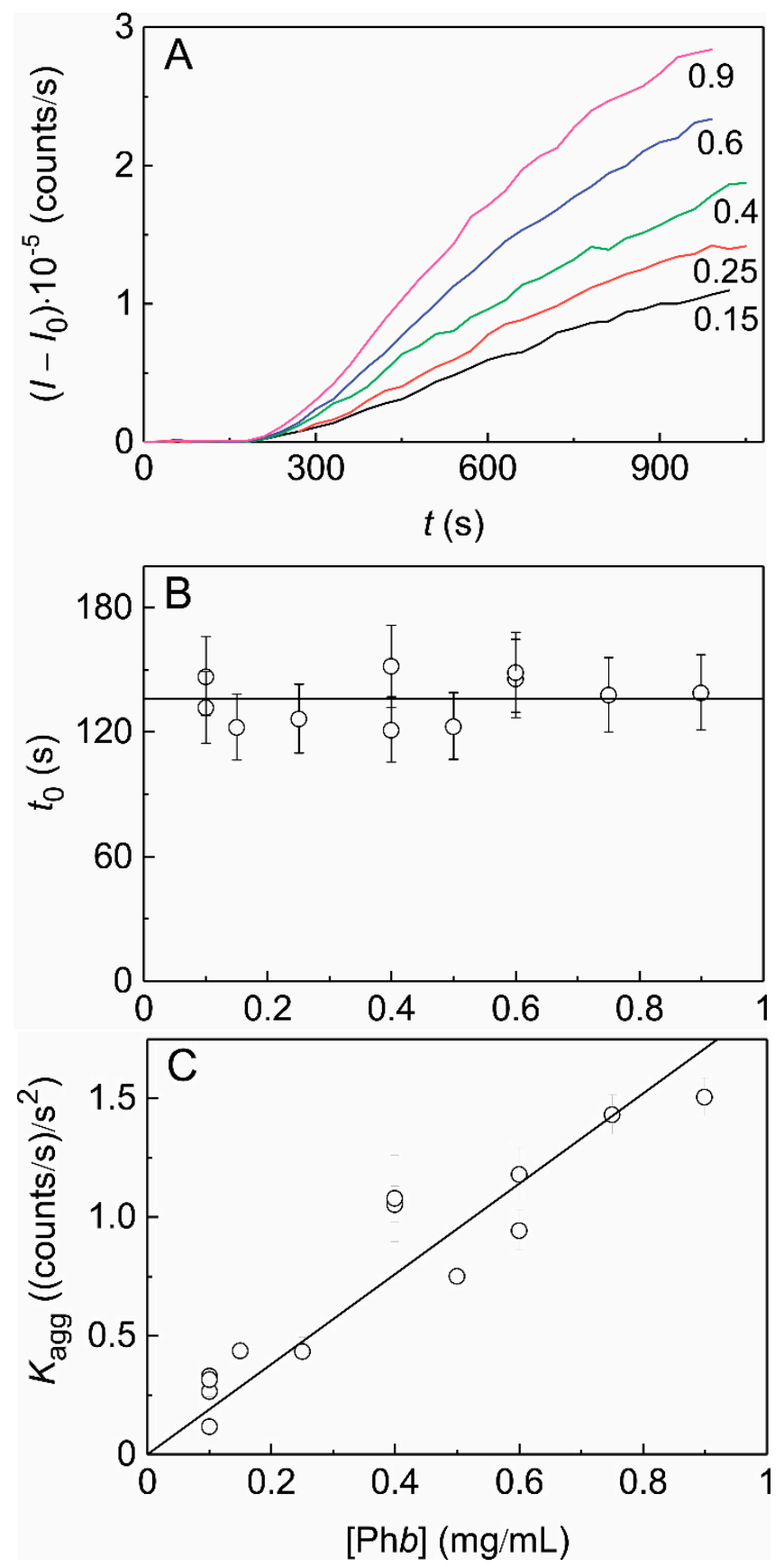

Figure 2. The kinetics of thermal aggregation of $\mathrm{Ph} b$ at $48^{\circ} \mathrm{C}$. (A)The dependences of the light scattering intensity $\left(I-I_{0}\right)$ on time $(t)$ for aggregation of $\mathrm{Ph} b$ at different protein concentrations (figures near the curves correspond to $\mathrm{Ph} b$ concentration in $\mathrm{mg} / \mathrm{mL}$ ). (B,C) The dependences of the parameters $t_{0}$ and $K_{\mathrm{agg}}$, respectively, calculated according to the Equation (1), on $\mathrm{Ph} b$ concentration. The solid lines in panels $(\mathbf{B}, \mathbf{C})$ are the linear approximations of the experimental data. 

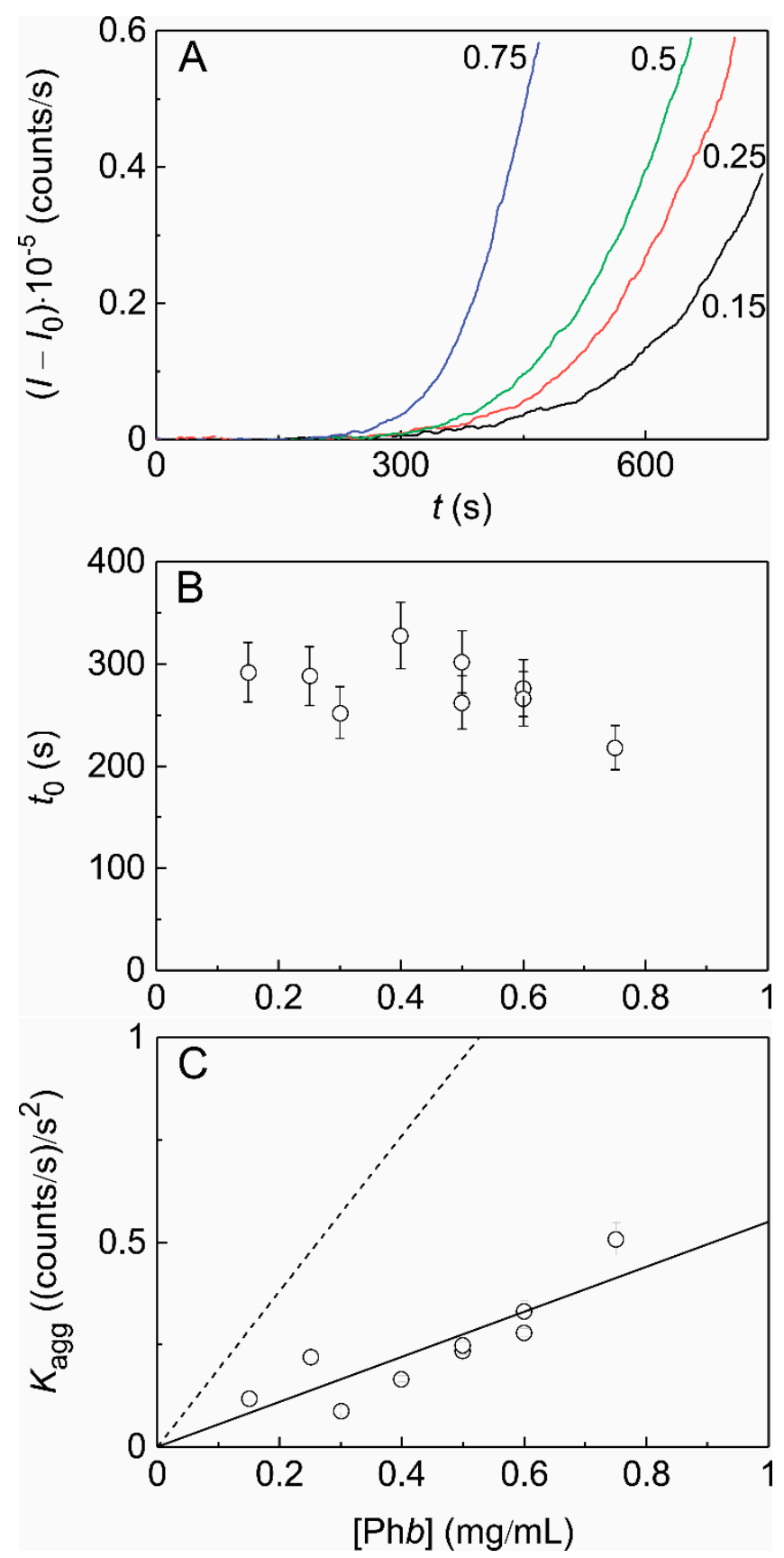

Figure 3. The kinetics of thermal aggregation of $\mathrm{Ph} b$ at $48^{\circ} \mathrm{C}$ registered in the presence of HSPB5. (A) The initial parts of the dependences of the light scattering intensity $\left(I-I_{0}\right)$ on time $(t)$ obtained for $\mathrm{Ph} b$ aggregation in the presence of HSPB5 $(0.025 \mathrm{mg} / \mathrm{mL})$ and various concentrations of Phb. Figures near the curves correspond to $\mathrm{Ph} b$ concentration in $\mathrm{mg} / \mathrm{mL}$. (B) The dependence of parameter $t_{0}$ on $\mathrm{Ph} b$ concentration. (C) The dependence of parameter $K_{\text {agg }}$ on $\mathrm{Ph} b$ concentration. The solid line is the linear approximation of the experimental data. The dashed line corresponds to the linear approximation of the dependence of $K_{\mathrm{agg}}$ on [Phb] for aggregation of $\mathrm{Ph} b$ in the absence of HSPB5.

Figure 4 shows that the protective action of HSPB 5 on the thermal aggregation of $\mathrm{Ph} b$ increases with increasing the sHSP concentration. As we can see in Figure 4A, the growth of the light scattering intensity becomes more flattened as the concentration of HSPB5 rises from 0.005 to $0.2 \mathrm{mg} / \mathrm{mL}$. Analysis of the $I(t)$ dependences using Equation (1) showed that the $t_{0}$ value increases with increasing HSPB5 concentration and becomes three times as much when HSPB5 concentration increases from 0 to 
$0.2 \mathrm{mg} / \mathrm{mL}$ (Figure 4B). As for parameter $K_{\mathrm{agg}}$, its value diminishes in a non-linear fashion when the concentration of HSPB5 increases (Figure 4C).
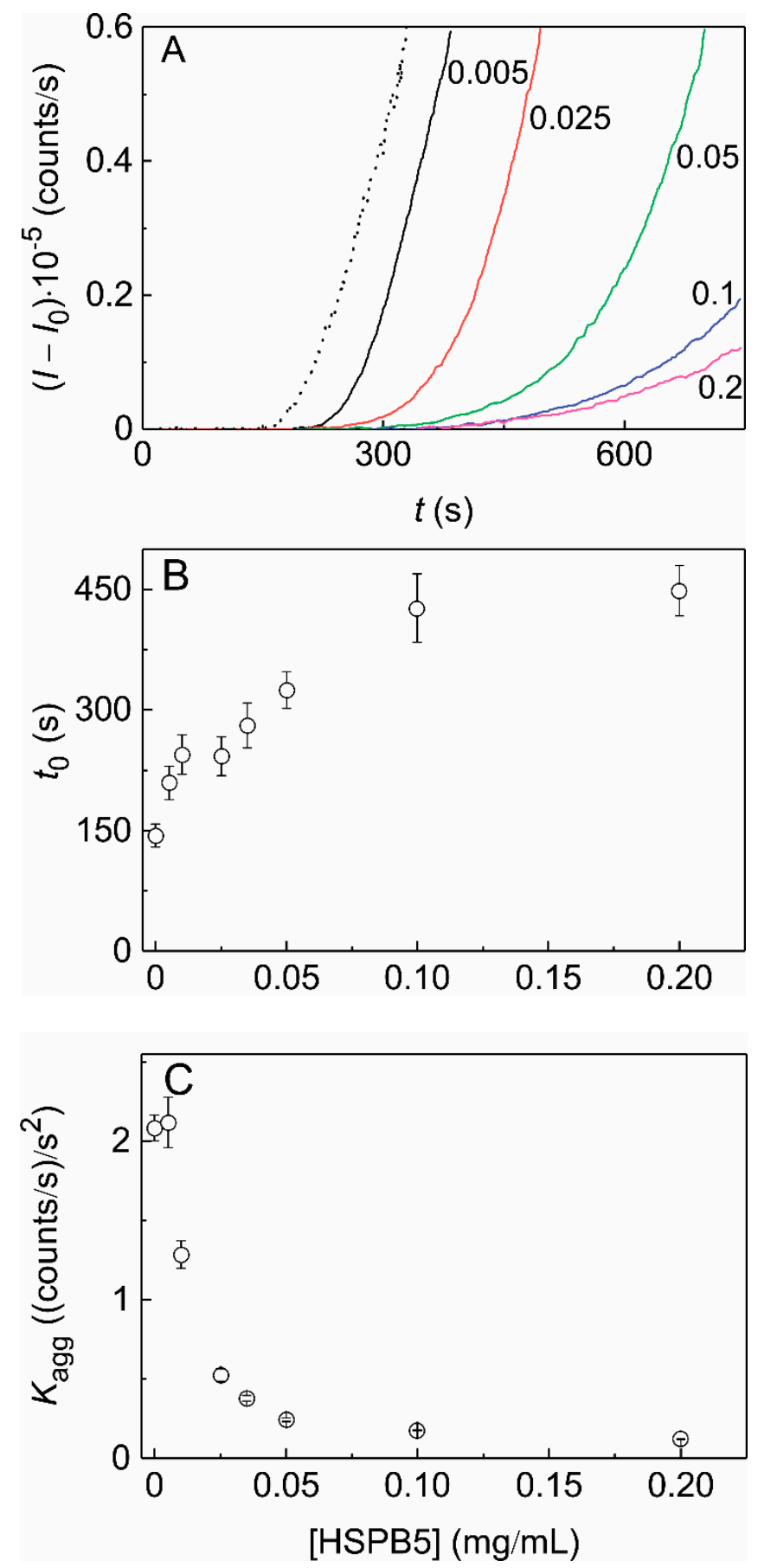

Figure 4. The effect of HSPB5 on the kinetics of thermal aggregation of $\mathrm{Ph} b$ at $48^{\circ} \mathrm{C}$. (A) The initial parts of the dependences of the light scattering intensity $\left(I-I_{0}\right)$ on time $(t)$ obtained for Ph $b$ aggregation $([\mathrm{Ph} b]=0.4 \mathrm{mg} / \mathrm{mL})$ at various concentrations of HSPB5. Figures near the curves correspond to HSPB5 concentration in $\mathrm{mg} / \mathrm{mL}$. The dotted line corresponds to the aggregation of $\mathrm{Ph} b$ alone. $(\mathbf{B}, \mathbf{C}) \mathrm{The}$ dependence of parameter $t_{0}$ on the concentration of HSPB5 and the dependence of parameter $K_{\mathrm{agg}}$ on the concentration of HSPB5, respectively. 
To characterize the anti-aggregation activity of HSPB5, the $\left(K_{\mathrm{agg}} / K_{\mathrm{agg}, 0}\right)^{1 / b} \equiv K_{\mathrm{agg}} / K_{\mathrm{agg}, 0}($ at $b=1)$ versus $x=[\mathrm{HSPB} 5] /[\mathrm{Ph} b]$ plot was constructed (Figure 5, $K_{\mathrm{agg}, 0}$ is the $K_{\mathrm{agg}}$ value measured in the absence of HSPB5). From the initial linear part of this dependence the initial adsorption capacity of HSPB5 $\left(A C_{0}\right)$ with respect to $\mathrm{Ph} b$ may be calculated as the reciprocal value of the length cut off by the straight line on the abscissa axis: $A C_{0}=1 / S_{0}=(3.2 \pm 0.2)$ monomers of Ph $b$ per one subunit of HSPB5. Thus, if we assume that HSPB5 forms tight complexes with $\mathrm{Ph} b$ as it is heated at $48{ }^{\circ} \mathrm{C}$, there might be 3.2 $\mathrm{Ph} b$ monomers per one subunit of HSPB5 in such complexes.

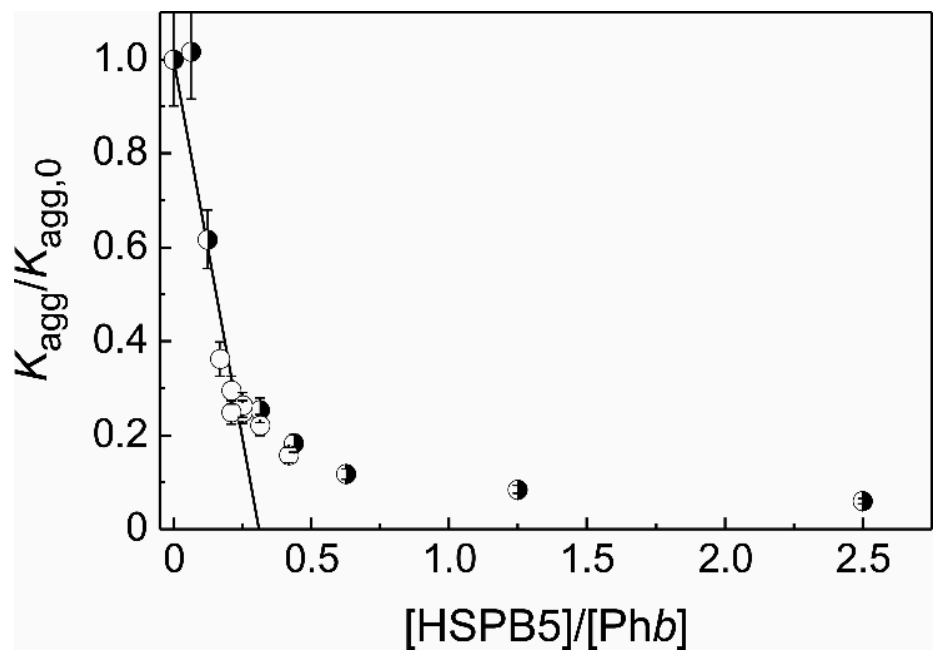

Figure 5. The suppression of $\mathrm{Ph} b$ aggregation by HSPB5. The dependence of $K_{\mathrm{agg}} / K_{\mathrm{agg}, 0}$ ratio on the ratio of molar concentrations of HSPB5 and $\mathrm{Ph} b(x=[\mathrm{HSPB} 5] /[\mathrm{Ph} b])$. Open circles correspond to $K_{\mathrm{agg}} / K_{\mathrm{agg}, 0}$ values at constant HSPB5 concentration $(0.025 \mathrm{mg} / \mathrm{mL})$. Half-filled circles correspond to $K_{\mathrm{agg}} / K_{\mathrm{agg}, 0}$ values at constant $\mathrm{Ph} b$ concentration $(0.4 \mathrm{mg} / \mathrm{mL})$. The solid line is calculated from the equation $K_{\mathrm{agg}} / K_{\mathrm{agg}, 0}=1-x / S_{0}$ at $S_{0}=0.31$.

As one can see in Figure 5, the full dependence of $K_{\mathrm{agg}} / K_{\mathrm{agg}, 0}$ on [HSPB5]/[Phb] is not linear. The complicated shape of the plot is probably due to the dynamic structure of HSPB5 and the initial part of this dependence corresponds to the complexes of the dissociated forms of the chaperone with the target protein. The non-linear part of this dependence corresponds to the formation of the HSPB5-target protein complexes where the adsorption capacity of HSPB5 in respect to the target protein becomes decreased.

Analysis of the DLS data allows for a conclusion that the observed increase in the light scattering intensity with time (Figure $4 \mathrm{~A}$ ) is caused by the growth of $\mathrm{Ph} b$ aggregates in size. Figure 6A shows the time dependences of the hydrodynamic radius $\left(R_{\mathrm{h}}\right)$ of protein aggregates formed in the course of thermal aggregation of $\mathrm{Ph} b$ in the absence and in the presence of HSPB5. Rising the concentration of HSPB5 from 0.005 to $0.2 \mathrm{mg} / \mathrm{mL}$ results in evident decrease in the size of registered aggregates.

It has been shown earlier that there is a linear relationship between the light scattering intensity $\left(I-I_{0}\right)$ and the $R_{\mathrm{h}}$ value for the initial parts of the kinetic curves observed for aggregation of $\mathrm{Ph} b$ at $48^{\circ} \mathrm{C}$ [65]. In the presence of HSPB5 the dependences of $\left(I-I_{0}\right)$ on $R_{\mathrm{h}}$ still be linear at the beginning of the aggregation process (Figure 6B). The length cut off on the abscissa axis by the linear dependence of $\left(I-I_{0}\right)$ on $R_{\mathrm{h}}$ corresponds to the hydrodynamic radius of the start aggregates $\left(R_{\mathrm{h}, 0}\right)$. The inset in Figure $6 \mathrm{~B}$ represents the $R_{\mathrm{h}, 0}$ values obtained for aggregation of $\mathrm{Ph} b$ in the presence of HSPB5 at various concentrations of the latter. The $R_{\mathrm{h}, 0}$ value was found to be $30 \pm 6 \mathrm{~nm}$ when $\mathrm{Ph} b$ aggregation was studied in the absence of HSPB5. The addition of HSPB5 at the concentration of $0.05 \mathrm{mg} / \mathrm{mL}$ results in more than 2.5-times size reduction of the start aggregates, and the $R_{\mathrm{h}, 0}$ value does not change with further increase in HSPB5 concentration up to $0.2 \mathrm{mg} / \mathrm{mL}$. 

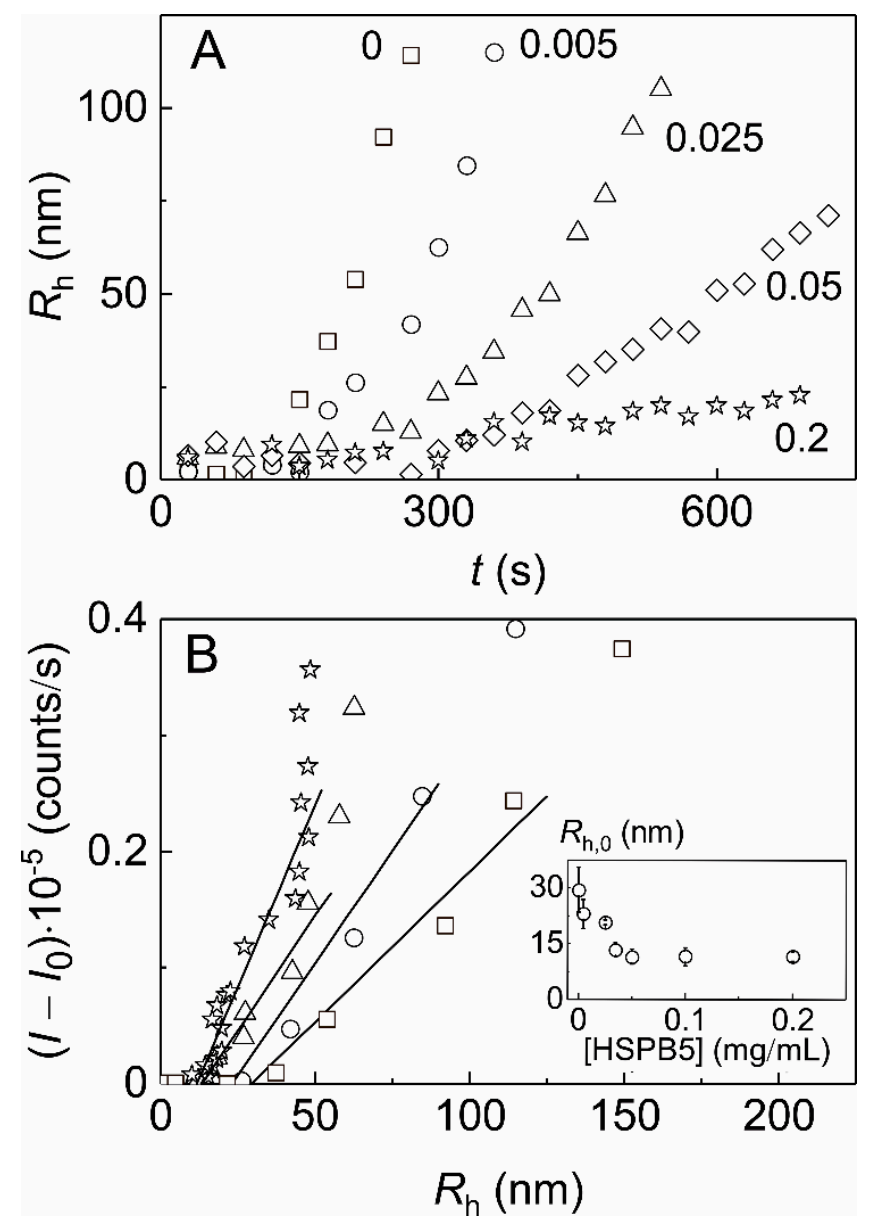

Figure 6. The effect of HSPB5on the thermal aggregation of $\mathrm{Ph} b$ at $48{ }^{\circ} \mathrm{C}$. (A) The dependences of the hydrodynamic radius $\left(R_{\mathrm{h}}\right)$ of $\mathrm{Ph} b$ aggregates on time $(t)$ obtained at various concentrations of HSPB5 ([Phb] $=0.4 \mathrm{mg} / \mathrm{mL}$; figures near the curves correspond to HSPB5 concentration in $\mathrm{mg} / \mathrm{mL}$ ). (B) The relationship between the light scattering intensity $\left(I-I_{0}\right)$ and the $R_{\mathrm{h}}$ values of $\mathrm{Ph} b$ aggregates in the absence of HSPB5 (squares) and in the presence of HSPB5 at the following concentrations: 0.005 (circles), 0.035 (triangles) and $0.2 \mathrm{mg} / \mathrm{mL}$ (stars). The solid lines are the linear approximations of the experimental data. The inset shows the dependence of the hydrodynamic radius of start aggregates $\left(R_{\mathrm{h}, 0}\right)$ on HSPB5 concentration.

\subsection{The Effect of HSPB5 on DTT-Induced Aggregation of $\alpha$-Lactalbumin ( $\alpha \mathrm{La}$ )}

To characterize the duration of the lag phase $\left(t_{0}\right)$ and the initial rate of the stage of aggregates growth, Equation (1) also can be used in the case of $\alpha$ La aggregation (0.1 M Na-phosphate buffer, $\mathrm{pH}$ 6.8) at $37^{\circ} \mathrm{C}$ in the presence of $20 \mathrm{mM}$ DTT [66]. The dependence of the parameter $K_{\text {agg }}$ on $\alpha \mathrm{La}$ concentration is linear in coordinates $\left\{\log ([\alpha \mathrm{La}]) ; \log \left(K_{\mathrm{agg}}\right)\right\}$ (Figure 7A). The slope of the linear fitting is equal to parameter $b$ in Equation (2), $(b=4.9 \pm 0.5)$. Thus, the stages of aggregation of $\alpha$ La become the rate limiting in the whole aggregation process, so that this test system allow testing the direct effect of various agents on the stage of aggregation of unfolded protein molecules [84]. 

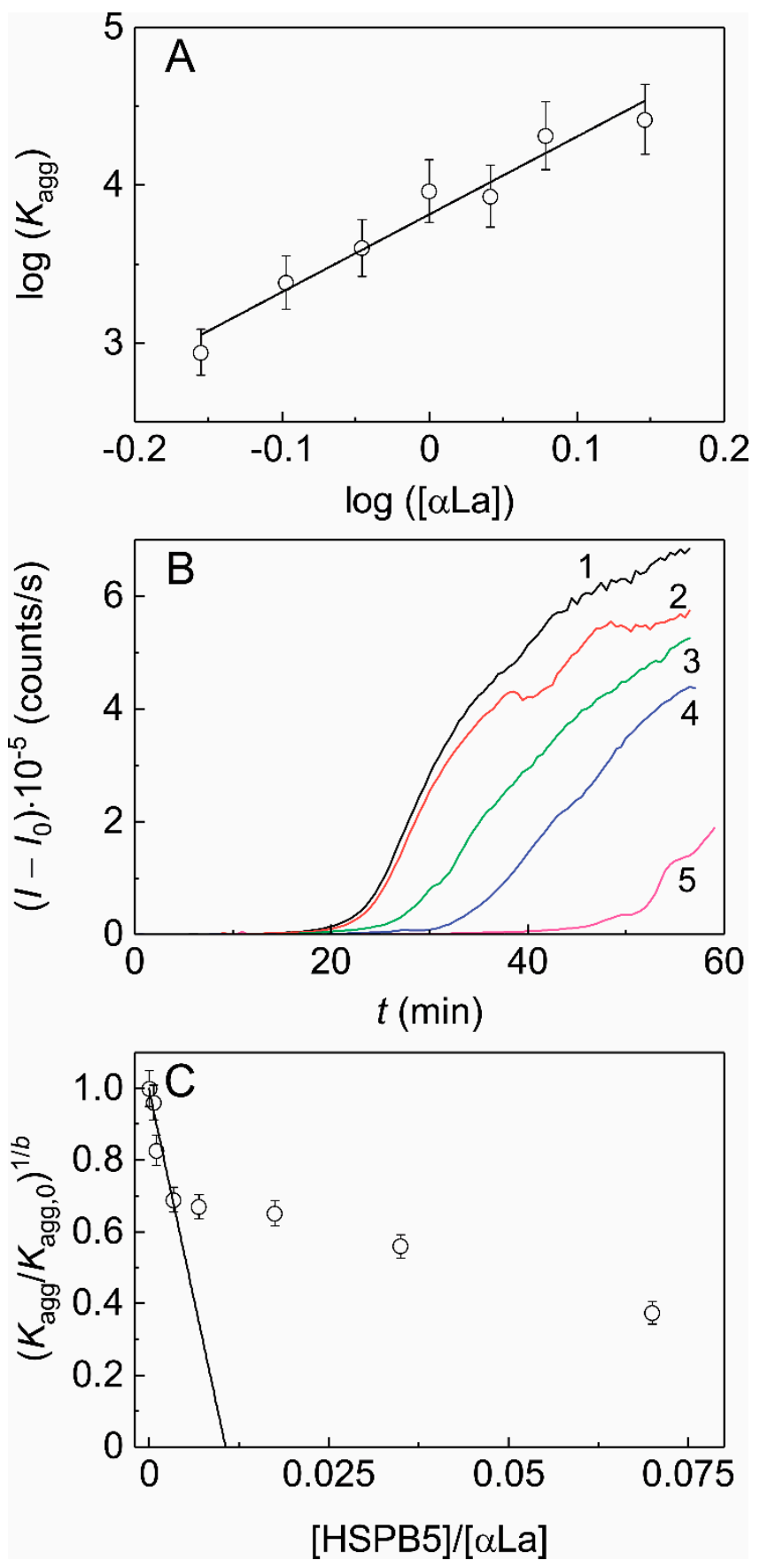

Figure 7. The effect of HSPB5 on DTT-induced aggregation of $\alpha$-lactalbumin $(\alpha \mathrm{La})$. (A) The relationship between parameter $K_{\mathrm{agg}}$ and the initial concentration of $\alpha \mathrm{La}$ in coordinates $\left\{\log ([\alpha \mathrm{La}]) ; \log \left(K_{\mathrm{agg}}\right)\right\}$. The slope of the linear fitting is equal to parameter $b(b=4.9 \pm 0.5)$. (B) The dependences of the light scattering intensity $(I)$ on time for $\alpha \mathrm{La}$ aggregation $([\alpha \mathrm{La}]=1 \mathrm{mg} / \mathrm{mL}, 0.1 \mathrm{M} \mathrm{Na}$-phosphate buffer, $\mathrm{pH} 6.8,20 \mathrm{mM} \mathrm{DTT}, 37^{\circ} \mathrm{C}$ ) in the absence of HSPB5 (curve1) and in the presence of the following concentrations of HSPB5: (2) 0.001, (3) 0.0025, (4) 0.0075 and (5) $0.025 \mathrm{mg} / \mathrm{mL}$. (C) The dependence of the relative parameter $\left(K_{\mathrm{agg}} / K_{\mathrm{agg}, 0}\right)^{1 / b}$ on the ratio of the molar concentrations of the chaperone and the target protein $(x)$. The linear fitting is drawn according to Equation (3).

Since it is known that the activity of a chaperone can be influenced/regulated by different target proteins, we compared the effect of HSPB5 on the kinetics of thermal aggregation of Phb with its effect on the kinetics of DTT-induced aggregation of $\alpha$ La. The comparison of test systems with different 
kinetic regimes and/or aggregation mechanisms can give an additional insight in the anti-aggregation functioning of chaperones, in this case in the functioning and related structural properties of sHSPs.

Figure 7B shows the dependences of the light scattering intensity $\left(I-I_{0}\right)$ on time for DTT-induced aggregation of $\alpha \mathrm{La}(1.0 \mathrm{mg} / \mathrm{mL})$ in the absence (curve 1) and presence of different concentrations of HSPB5 (curves 2-5). The suppression of the increment of the light scattering intensity in time with increasing HSPB 5 concentration was observed and can be characterized by parameters $K_{\text {agg }}$ and $t_{0}$. As in the case of $\mathrm{Ph} b$, the dependence of the relative parameter $\left(K_{\mathrm{agg}} / K_{\mathrm{agg}, 0}\right)^{1 / b}$ on the ratio of the molar concentrations of HSPB5 and $\alpha$ La was plotted (Figure 7C). The initial stoichiometry of the HSPB5- $\alpha$ La complexes $\left(S_{0}\right)$ determined using Equation (3) was found to be equal to $0.011 \pm 0.001$. Thus, we may evaluate the adsorption capacity of HSPB 5 with respect to $\alpha \mathrm{La}$ at the initial stages of aggregation: $A C_{0}=1 / S_{0}=(91 \pm 8) \alpha \mathrm{La}$ molecules per one HSPB5 subunit.

\subsection{Sedimentation Velocity (SV) Analysis of HSPB5 and $\alpha$-Lactalbumin at $37{ }^{\circ} \mathrm{C}$}

SV analysis made it possible to verify the interaction of $\alpha$ La with HSPB5 at low concentrations of the latter. Figure 8 shows the differential sedimentation coefficient distribution, $c(s)$, for $\alpha$ La denatured by the addition of $20 \mathrm{mM}$ DTT at $37^{\circ} \mathrm{C}$. The $c(s)$ distribution exhibits a broad peak with a sedimentation coefficient $\left(s_{20, \mathrm{w}}\right)$ of $2.8 \mathrm{~S}$ and a minor peak $(\sim 3 \%)$ with $s_{20, \mathrm{w}}$ of $6.1 \mathrm{~S}$, which indicates the presence of a mixture of denatured monomers, dimers and small aggregates of $\alpha \mathrm{La}$.

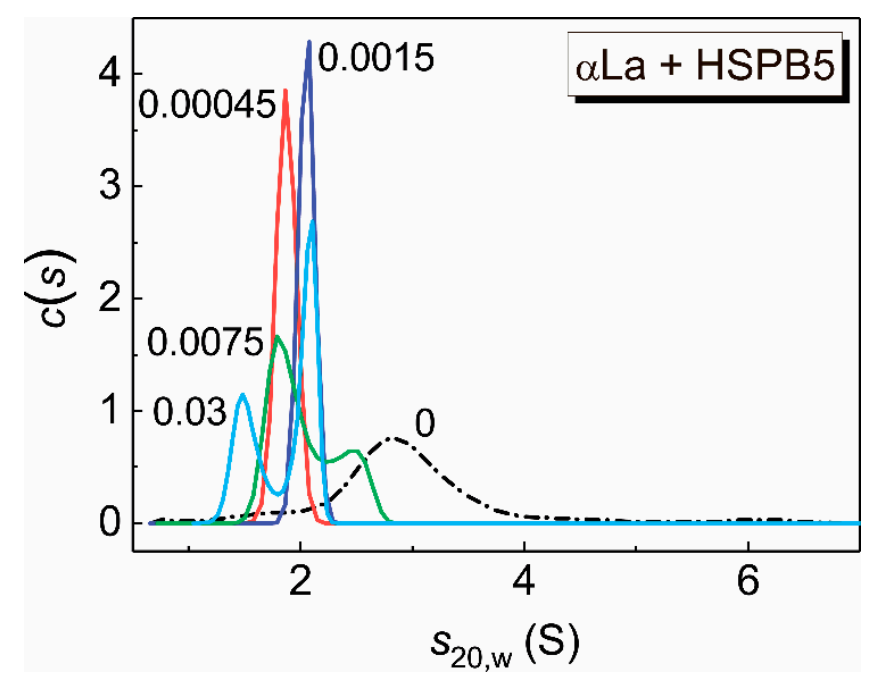

Figure 8. The sedimentation behavior of $\alpha$ La denatured by the addition of $20 \mathrm{mM}$ DTT in the presence of HSPB5 at $37^{\circ} \mathrm{C}$. The differential sedimentation coefficient distributions, $c(s)$, for $\alpha \mathrm{La}(0.3 \mathrm{mg} / \mathrm{mL})$ at various concentrations of HSPB5. Figures near the curves correspond to HSPB5 concentration in $\mathrm{mg} / \mathrm{mL}$. The $c(s)$ distributions were transformed to standard conditions. Rotor speed was $60,000 \mathrm{rpm}$. The total time of the experiment at the elevated temperature was $140 \mathrm{~min}$.

The data obtained by asymmetric field flow (Figure S1) also show that after 3 min incubation at $37^{\circ} \mathrm{C}$ in the presence of $20 \mathrm{mM} \mathrm{DTT}$, denatured $\alpha$ La exists during $30 \mathrm{~min}$ as a mixture of monomers, dimers and small aggregates.

In the case when HSPB 5 at concentration of $0.00045 \mathrm{mg} / \mathrm{mL}$ was added, the $c(s)$ distribution shows the main narrow peak with $s_{20, \mathrm{w}}=1.9 \mathrm{~S}$. Unfortunately, it is impossible to verify the oligomeric state of HSPB5 at such a low chaperone concentration by the SV method using an absorption optical system, but earlier we showed that the dissociation of HSPB5 occurs when the chaperone concentration decreases [32]. It can be assumed that the chaperone exists in a dimeric or monomeric form at such a low concentration. The $c(s)$ distribution of $\alpha \mathrm{La}$ is shifted toward smaller values on the addition of HSPB5, indicating the formation of hetero-complexes. With an increase in the concentration of HSPB5, the position of the peak in the $c(s)$ distribution changes and the peak splits into 2 peaks with 
the sedimentation coefficients of 1.6 and $2.0 \mathrm{~S}$ at the HSPB5 concentration of $0.03 \mathrm{mg} / \mathrm{mL}$ (or $2.1 \mu \mathrm{M}$ ). The data obtained indicate that the $\alpha$ La dimer may dissociate into monomers in the presence of the chaperone during denaturation. The interaction of HSPB 5 with $\alpha$ La results in the formation of small hetero-oligomers that differ in the molar mass and shape. The molar masses estimated by SEDFIT are given in Table 1. The molecular mass varies from 25 to $37-47 \mathrm{kDa}$ with an increase in the concentration of the chaperone. The value of the molar mass equal to $26 \mathrm{kDa}$ can correspond to dimers of the target protein, taking into account that the molecular mass of $\alpha$ La monomer is $14.2 \mathrm{kDa}$, and values of the molar mass of 37-47 kDa can correspond to complexes between $\alpha$ La monomer and HSPB5 monomer (with a subunit mass of $20 \mathrm{kDa}$ ) or complexes between a dimer of the target protein and a monomer of the chaperone ( $47 \mathrm{kDa})$. However, the existence of high-order oligomeric HSPB5- $\alpha$ La complexes cannot be ruled out. Such complexes may be present in DLS measurements. The typical particle size time-dependences for aggregates of $\alpha \mathrm{La}(1.0 \mathrm{mg} / \mathrm{mL})$ in the absence or presence of HSPB5 are shown in Figure S2 of the Supplementary Materials.

Table 1. Estimation of the molar mass and $s_{20, \mathrm{w}}$ values of the complexes between HSPB5 and $\alpha$ La denatured by $20 \mathrm{mM}$ DTT (0.1 M Na-phosphate buffer, $\left.0.01 \mathrm{M} \mathrm{NaCl}, \mathrm{pH} 6.8,37^{\circ} \mathrm{C}\right)$.

\begin{tabular}{cccc}
\hline [HSPB5] $(\mathbf{m g} / \mathbf{m L})$ & $\boldsymbol{s}_{\mathbf{2 0 , \mathbf { w }}}(\mathbf{S})$ & Friction Ratio, $f / f_{\mathbf{0}}$ & Molecular Mass $(\mathbf{k D a})$ \\
\hline 0 & $2.9 \pm 0.8$ & 2.7 & \\
0.00045 & $6.1 \pm 0.4$ & 1.614 & \\
0.0015 & $1.85 \pm 0.13$ & 1.545 & 25.4 \\
0.0075 & $2.0 \pm 0.1$ & 1.925 & 33 \\
& $1.9 \pm 0.2$ & & 47 \\
0.03 & $2.4 \pm 0.3$ & 1.836 & 23.9 \\
& $1.6 \pm 0.2$ & & 37.4 \\
\hline
\end{tabular}

\subsection{Sedimentation Velocity Analysis of HSPB5 and Phb at $48^{\circ} \mathrm{C}$}

Figure 9 shows the sedimentation behavior of $\mathrm{Ph} b$ in the presence of low concentrations of HSPB5 at $48^{\circ} \mathrm{C}$. The $c(s)$ distribution for $\mathrm{Ph} b(0.5 \mathrm{mg} / \mathrm{mL})$ exhibits one main peak and several small peaks, which may correspond to a partially unfolded dimer $\left(s_{20, \mathrm{w}}=7.7 \mathrm{~S}\right)$, the denatured monomer $\left(s_{20, \mathrm{w}}=6.6 \mathrm{~S}\right)$ and a small amount of the native dimer $\left(s_{20, \mathrm{w}}=8.6 \mathrm{~S}\right)$. In addition, during the acceleration of the rotor, about $17 \%$ of the protein aggregated and precipitated. In the presence of even small concentrations of HSPB5, the position of the main peak $(7.7 \pm 0.1 \mathrm{~S})$ is shifted toward the higher values (Figure 9, $s_{20, \mathrm{w}}=8.0 \pm 0.1 \mathrm{~S}$ and $8.2 \pm 0.2 \mathrm{~S}$ in the presence of 0.025 and $0.075 \mathrm{mg} / \mathrm{mL}$ HSPB5, respectively), and the positions of minor peaks change, that indicates the interaction of the chaperone with the target protein. As for the main peak, the sedimentation coefficient value increases, that means an increase in the molecular mass of the complex, on the one hand, and a change in the conformation of the target protein, on the other. The molecular mass estimate for the main peaks of $\mathrm{Ph} b$ in the absence and presence of HSPB5 at concentrations of 0.025 and $0.075 \mathrm{mg} / \mathrm{mL}$ (Figure 9) using Svedberg equation (see Section 4.3) gives the values: $205 \pm 10,234 \pm 10$ and $230 \pm 10 \mathrm{kDa}$, respectively. For calculations, we used sedimentation coefficients determined by AUC and diffusion coefficients $(D)$, determined by DLS at $48^{\circ} \mathrm{C}$. The coefficients $D$ for Phb and possible complexes of Ph $b$ with HSPB5 were estimated to be $(6.5 \pm 0.3) \times 10^{-7},(5.9 \pm 0.5) \times 10^{-7},(6.2 \pm 0.3) \times 10^{-7} \mathrm{~cm}^{2} / \mathrm{s}$. The $R_{\mathrm{h}}$ values obtained by DLS method were equal to $6.2,6.9$ and $6.4 \mathrm{~nm}$, respectively. The data of SV analysis and data obtained by DLS method indicate the possibility of the formation of complexes between the dimeric form of the $\mathrm{Ph} b$ and the monomeric or dimeric form of HSPB5. 


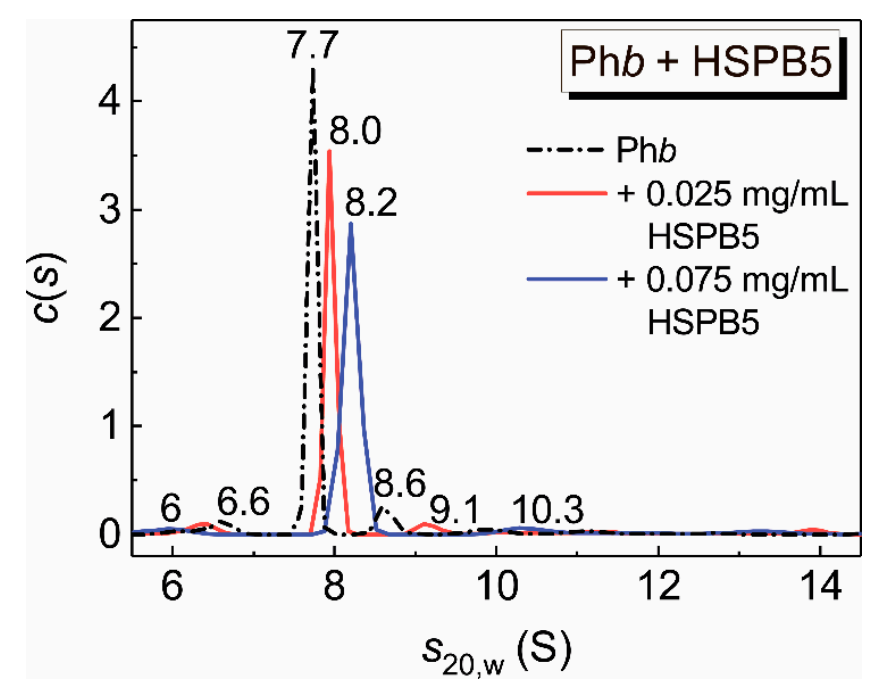

Figure 9. Interaction of $\mathrm{Ph} b$ with $\mathrm{HSPB} 5$ at $48{ }^{\circ} \mathrm{C}$. (A) Differential distributions $c(s)$ for $\mathrm{Ph} b$ alone $(0.5 \mathrm{mg} / \mathrm{mL}$; dash dot line) and the mixtures of $\mathrm{Ph} b(0.5 \mathrm{mg} / \mathrm{mL})$ and HSPB5 at the following concentrations: $0.025 \mathrm{mg} / \mathrm{mL}$ (red) and $0.075 \mathrm{mg} / \mathrm{mL}$ (blue). The $c(s)$ distributions were corrected to the standard conditions. Rotor speed was $48,000 \mathrm{rpm}$. The total time of the experiment at the elevated temperature was $90 \mathrm{~min}$.

\subsection{Sedimentation Velocity Analysis of HSPB5 and Phb at $48^{\circ} \mathrm{C}$ Under Crowded Conditions}

A comparison of the $c(s)$ distributions for $\mathrm{Ph} b$ and the mixtures of $\mathrm{Ph} b$ and HSPB5 under crowded conditions arising from the presence of $\mathrm{PEG}_{20 \mathrm{kDa}}(25 \mathrm{mg} / \mathrm{mL})$ revealed a shift in the position of the major peak from $s_{20, \mathrm{w}}=10.3 \mathrm{~S}$ for Phb to $s_{20, \mathrm{w}}=9.8 \mathrm{~S}$ for the mixture (Figure 10).

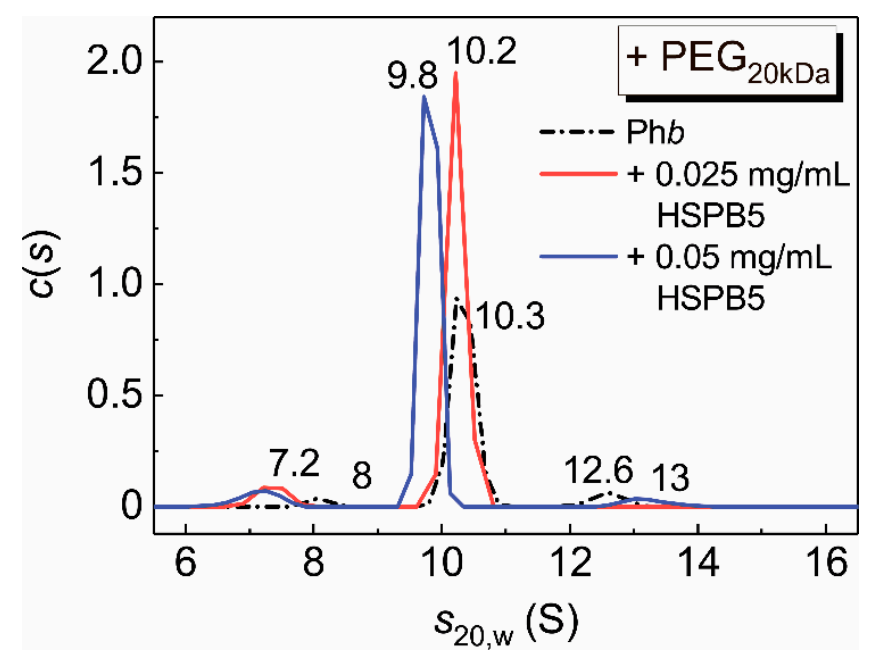

Figure 10. The $c(s)$ distributions for the mixtures of $\mathrm{Ph} b(0.5 \mathrm{mg} / \mathrm{mL})$ and HSPB5 in the presence of $\mathrm{PEG}_{20 \mathrm{kDa}}(25 \mathrm{mg} / \mathrm{mL})$. The following concentrations of HSPB5 were used: 0 (black), $0.025 \mathrm{mg} / \mathrm{mL}$ (red) and $0.05 \mathrm{mg} / \mathrm{mL}$ (blue). The $c(s)$ distributions were corrected to the standard conditions. Rotor speed was $48,000 \mathrm{rpm}$. The total time of the experiment at the elevated temperature was $90 \mathrm{~min}$.

This shift, combined with the increasing area under the major peak on the $c(s)$ distributions for the mixtures of HSPB5 and Phb (Figure 10, red and blue curves), indicates the interaction between the chaperone and the target protein under crowded conditions. Crowding can both stabilize the target protein at the denaturation stage of the aggregation process and accelerate the process at the aggregation stage. The amount of the protein aggregated and precipitated during rotor acceleration 
increased from $17 \%$, in the case of sedimentation of $\mathrm{Ph} b$ in the dilute solution (Hepes buffer), up to $37 \%$ for $\mathrm{Ph} b$ sedimentation in the presence of $\mathrm{PEG}_{20 \mathrm{kDa}}$.

The addition of HSPB5 protects $\mathrm{Ph} b$ from precipitation. The fraction of the precipitated protein decreases by almost twofold (up to 19\%) in the presence of the chaperone (data not shown). This also indicates the interaction between the chaperone and the target protein under crowded conditions. Although we cannot obtain the sedimentation behavior of HSPB5 itself at the concentrations used, according to our earlier data HSPB5 appears to dissociate at elevated temperature in a concentration dependent manner [25,32]. Thus, HSPB5 may be in a dissociated form (dimeric or monomeric) at such low concentrations in a buffer solution. However, under crowded conditions, the chaperone assembles into large-sized oligomers at $48^{\circ} \mathrm{C}$ [25].

The interaction of HSPB5 with $\mathrm{Ph} b$ under the mixed crowding and the heat stress conditions was studied by the sedimentation velocity analysis. The data of SV analysis are presented in Figure 11. In the case of HSPB5 the $c(s)$ distribution contains the main narrow peak with $s_{20, w}=23 \mathrm{~S}$, which is consistent with our earlier data [25]. This value, $23 \mathrm{~S}$, corresponds to a large oligomer assembly with the molar mass of $621 \mathrm{kDa}$ [25]. The $c(s)$ distribution for partially denatured $\mathrm{Ph} b$ reveals several peaks with sedimentation coefficients of 7,9,12S and several minor peaks corresponding to small aggregates. A comparison of individual distributions for the chaperone and the target protein with that for the mixture of HSPB5 and $\mathrm{Ph} b$ reveals that the peak at $23 \mathrm{~S}$ disappears, the peak at $7 \mathrm{~S}$ also disappears, the area under the peak at $9 \mathrm{~S}$ decreases significantly in the $c(s)$ distribution for the mixture. At the same time new peaks appear for the mixture with the values of $s_{20, w}$ less or greater than $23 \mathrm{~S}$, namely, peaks at 11, 14, $16 \mathrm{~S}$ and 25, $31 \mathrm{~S}$, respectively. These data can be explained by the dissociation of the chaperone upon encountering a target protein and the formation of complexes of different sizes and masses between the suboligomeric forms of HSPB5 and $\mathrm{Ph} b$.

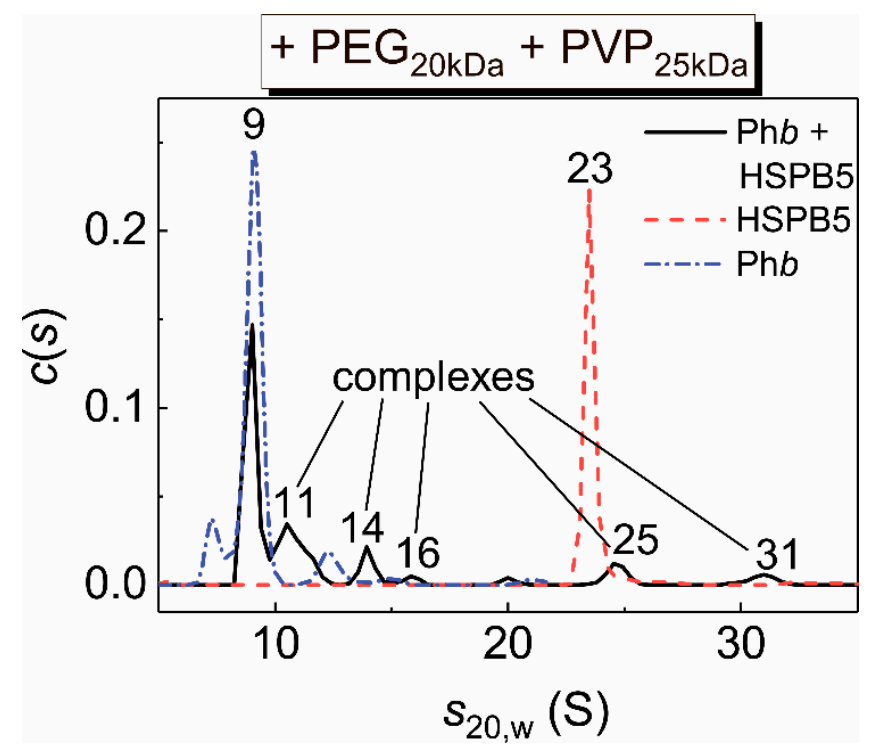

Figure 11. Interaction of $\mathrm{HSPB} 5$ with $\mathrm{Ph} b$ as a target protein at $48^{\circ} \mathrm{C}$ under crowded conditions arising from the presence of the mixture of $\mathrm{PEG}_{20 \mathrm{kDa}}(25 \mathrm{mg} / \mathrm{mL})$ and $\mathrm{PVP}_{25 \mathrm{kDa}}(12.5 \mathrm{mg} / \mathrm{mL})$. The differential sedimentation coefficient distributions, $c(s)$, for Phb $(0.4 \mathrm{mg} / \mathrm{mL}$; dash dot blue line), HSPB5 $(0.26 \mathrm{mg} / \mathrm{mL}$; dash red line) and its mixture (solid black line) are presented. The $c(s)$ distributions were obtained at $48^{\circ} \mathrm{C}$ and transformed to standard $s_{20, w}$ distributions. Rotor speed was $48,000 \mathrm{rpm}$. The total time of the sedimentation experiment at the elevated temperature was about $90 \mathrm{~min}$.

\subsection{Effect of Crowding on the Chaperone-Like Activity of HSPB5}

The effects of four macromolecular crowders $\left(\mathrm{PEG}_{20 \mathrm{kDa}}, \mathrm{PVP}_{10 \mathrm{kDa}}, \mathrm{PVP}_{25 \mathrm{kDa}}\right.$, Ficoll $\left.70 \mathrm{kDa}\right)$ and five mixed pairs of crowders $\left(\mathrm{PEG}_{20 \mathrm{kDa}}+\right.$ Ficoll $70 \mathrm{kDa}, \mathrm{PVP}_{10 \mathrm{kDa}}+$ Ficoll $70 \mathrm{kDa}, \mathrm{PVP}_{25 \mathrm{kDa}}+$ Ficoll $_{70 \mathrm{kDa}}$, $\mathrm{PVP}_{10 \mathrm{kDa}}+\mathrm{PEG}_{20 \mathrm{kDa}}, \mathrm{PVP}_{25 \mathrm{kDa}}+\mathrm{PEG}_{20 \mathrm{kDa}}$ ) on the kinetics of heat-induced aggregation of $\mathrm{Ph} b$ were 
evaluated by measuring the increment of the light scattering intensity with time. We selected the parameter $K_{\mathrm{agg}}$ for quantitative assessing the effect of crowding on the chaperone-like activity of HSPB5. Table 2 shows that crowding has a significant effect on the kinetic parameters of the protein aggregation and on the chaperone-like activity of HSPB5. All the crowders and their mixtures shorten the lag time $t_{0}$ and increase the $K_{\mathrm{agg}}$ value and the $K_{\mathrm{agg}} / K_{\mathrm{agg}}^{0}$ ratio, where $K_{\mathrm{agg}}^{0}$ is the $K_{\mathrm{agg}}$ value measured in the presence of HSPB5 and in the absence of any crowders. The greatest decrease in the lag period (1.6 times) and an increase in the relative rate of aggregation of $\mathrm{Ph} b$ (the value of the parameter $K_{\mathrm{agg}} / K_{\mathrm{agg}}^{0}$ increases by 55 times) occurs in the presence of a mixture of two polymers $\left(\mathrm{PVP}_{25 \mathrm{kDa}}+\mathrm{PEG}_{20 \mathrm{kDa}}\right)$. That is, crowding reduces the chaperone-like activity of HSPB5.

Table 2. Kinetic parameters for aggregation of $\mathrm{Ph} b(0.4 \mathrm{mg} / \mathrm{mL})$ in the presence of HSPB5 at a concentration of $0.025 \mathrm{mg} / \mathrm{mL}$ at $48{ }^{\circ} \mathrm{C}(0.03 \mathrm{M}$ Hepes buffer, $0.1 \mathrm{M} \mathrm{NaCl}, 0.2 \mathrm{mM}$ EDTA, pH $6.8)$.

\begin{tabular}{|c|c|c|c|c|}
\hline Additions & $\begin{array}{c}K_{\mathrm{agg}} \\
((\text { counts/s)/s})\end{array}$ & $t_{0}(\mathrm{~s})$ & $K_{\mathrm{agg}} / K_{\mathrm{agg}}^{0}{ }^{1}$ & $j$ \\
\hline \multicolumn{5}{|c|}{ Without addition of crowding agents } \\
\hline- & $0.123 \pm 0.007$ & $323 \pm 9$ & 1.0 & - \\
\hline \multicolumn{5}{|c|}{ Action of individual crowding agents } \\
\hline $\mathrm{PEG}_{20 \mathrm{kDa}} 25 \mathrm{mg} / \mathrm{mL}$ & $1.85 \pm 0.04$ & $287 \pm 2$ & $15.0 \pm 0.9$ & - \\
\hline $\mathrm{PVP}_{10 \mathrm{kDa}} 25 \mathrm{mg} / \mathrm{mL}$ & $0.28 \pm 0.01$ & $266 \pm 5$ & $2.3 \pm 0.2$ & - \\
\hline $\mathrm{PVP}_{25 \mathrm{kDa}} 25 \mathrm{mg} / \mathrm{mL}$ & $0.52 \pm 0.02$ & $232 \pm 5$ & $4.2 \pm 0.3$ & - \\
\hline Ficoll $70 \mathrm{kDa}$ $75 \mathrm{mg} / \mathrm{mL}$ & $0.144 \pm 0.015$ & $252 \pm 12$ & $1.17 \pm 0.14$ & - \\
\hline \multicolumn{5}{|c|}{ Combined action of crowding agents } \\
\hline $\begin{array}{c}\text { PEG20kDa } 25 \mathrm{mg} / \mathrm{mL}+\text { Ficoll70kDa } \\
75 \mathrm{mg} / \mathrm{mL}\end{array}$ & $1.37 \pm 0.05$ & $196 \pm 4$ & $11.1 \pm 0.8$ & $0.71 \pm 0.06$ \\
\hline $\mathrm{PVP}_{10 \mathrm{kDa}} 25 \mathrm{mg} / \mathrm{mL}+$ Ficoll $_{70 \mathrm{kDa}} 75 \mathrm{mg} / \mathrm{mL}$ & $1.69 \pm 0.05$ & $263 \pm 3$ & $13.7 \pm 0.9$ & $8.8 \pm 0.6$ \\
\hline $\mathrm{PVP}_{25 \mathrm{kDa}} 25 \mathrm{mg} / \mathrm{mL}+$ Ficoll $_{70 \mathrm{kDa}} 75 \mathrm{mg} / \mathrm{mL}$ & $3.76 \pm 0.21$ & $240 \pm 3$ & $30.6 \pm 2.4$ & $8.7 \pm 0.7$ \\
\hline $\mathrm{PVP}_{10 \mathrm{kDa}} 25 \mathrm{mg} / \mathrm{mL}+\mathrm{PEG}_{20 \mathrm{kDa}} 25 \mathrm{mg} / \mathrm{mL}$ & $4.00 \pm 0.22$ & $227 \pm 3$ & $32.5 \pm 2.6$ & $2.06 \pm 0.17$ \\
\hline $\mathrm{PVP}_{25 \mathrm{kDa}} 25 \mathrm{mg} / \mathrm{mL}+\mathrm{PEG}_{20 \mathrm{kDa}} 25 \mathrm{mg} / \mathrm{mL}$ & $6.76 \pm 0.29$ & $203 \pm 2$ & $55 \pm 4$ & $3.12 \pm 0.23$ \\
\hline
\end{tabular}

When assessing the effect of mixed crowding, synergism or antagonism in the action of crowders in a pair can be evaluated. To characterize the combined action of crowding agents, parameter $j$ can be proposed:

$$
j=\frac{\left(K_{\mathrm{agg}}^{1,2} / K_{\mathrm{agg}}^{0}\right)-1}{\left[\left(K_{\mathrm{agg}}^{1} / K_{\mathrm{agg}}^{0}\right)-1\right]+\left[\left(K_{\mathrm{agg}}^{2} / K_{\mathrm{agg}}^{0}\right)-1\right]}
$$

where $K_{\mathrm{agg}}^{0}$ is the $K_{\mathrm{agg}}$ value measured in the presence of HSPB5 and in the absence of any crowders, $K_{\text {agg }}^{1}, K_{\text {agg }}^{2}$ and $K_{\text {agg }}^{1,2}$ are the $K_{\text {agg }}$ values measured in the presence of both HSPB5 and crowder 1 , crowder 2 , or their mixture, respectively. When the action of two crowding agents is independent, parameter $j$ is equal to unity. When $j>1$ there is a synergism in the combined action of two crowding agents, and the case $j<1$ corresponds to the antagonism in their action. So slight antagonism was detected for the couple $\left(\mathrm{PEG}_{20 \mathrm{kDa}}+\right.$ Ficoll $\left._{70 \mathrm{kDa}}\right)$. In contrast, synergism in the combined action was shown for pairs $\left(\mathrm{PVP}_{10 \mathrm{kDa}}+\right.$ Ficoll $70 \mathrm{kDa} ; \mathrm{PVP}_{25 \mathrm{kDa}}+$ Ficoll $\left._{70 \mathrm{kDa}} ; \mathrm{PVP}_{10 \mathrm{kDa}}+\mathrm{PEG}_{20 \mathrm{kDa}} ; \mathrm{PVP}_{25 \mathrm{kDa}}+\mathrm{PEG}_{20 \mathrm{kDa}}\right)$. The diagram in Figure S3 (in the Supplementary Materials) illustrates graphically the antagonism of the action in the case of a mixture $\left(\mathrm{PEG}_{20 \mathrm{kDa}}+\right.$ Ficoll $\left._{70 \mathrm{kDa}}\right)$ and the synergism for pairs $\left(\mathrm{PVP}_{10 \mathrm{kDa}}+\right.$ Ficoll $70 \mathrm{kDa} ; \mathrm{PVP}_{25 \mathrm{kDa}}+$ Ficoll $\left.70 \mathrm{kDa} ; \mathrm{PVP}_{10 \mathrm{kDa}}+\mathrm{PEG}_{20 \mathrm{kDa}} ; \mathrm{PVP}_{25 \mathrm{kDa}}+\mathrm{PEG}_{20 \mathrm{kDa}}\right)$ in the presence of HSPB5. 
It can be seen from the diagram (Figure S3) that crowders can have different effects on $K_{\text {agg }}$ in the absence of HSPB5. The presence of crowders in the absence of HSPB5 can not only increase the parameter $K_{\mathrm{agg}}$ (in the case of $\mathrm{PVP}_{25 \mathrm{kDa}} ; \mathrm{PVP}_{25 \mathrm{kDa}}+\mathrm{PEG}_{20 \mathrm{kDa}}$ ), which is the expected effect due to excluded volume, but also reduce $K_{\mathrm{agg}}$ (in the case of PEG; PVP $10 \mathrm{kDa}$; Ficoll ${ }_{70 \mathrm{kDa}}$; $\mathrm{PVP}_{10 \mathrm{kDa}}+$ Ficoll $70 \mathrm{kDa} ; \mathrm{PVP}_{25 \mathrm{kDa}}+$ Ficoll $70 \mathrm{kDa} ; \mathrm{PVP}_{10 \mathrm{kDa}}+\mathrm{PEG}_{20 \mathrm{kDa}}$ and $\mathrm{PEG}_{20 \mathrm{kDa}}+$ Ficoll $70 \mathrm{kDa}$ ) (Figure S1, panel A). This deceleration of the $\mathrm{Ph} b$ aggregation can be explained by the action of three factors, such as: (1) an increase in the viscosity of the solution (see Table S1), (2) the effect of crowding on the stage of denaturation of the $\mathrm{Ph} b$, (3) weak interactions between the target protein and crowders. Figure S3 (panel B) shows that nucleation time, $t_{0}$, decreases both in the presence and in the absence of the chaperone. Thus, our data obtained by DLS method allow us to suggest that the chaperone-like activity of HSPB5 decreases under crowded conditions.

\section{Discussion}

It is well known that the dynamics and polydispersity of oligomers play an important role in the functioning of $\alpha$-crystallins $[10,29,90,91]$. It was reported that subunit exchange promotes structural reorganization within the homo-oligomers of $\alpha \mathrm{B}$-crystallin [27] (see review [29]). The equilibrium between oligomeric forms is very sensitive to many factors such as temperature $[1,27,92-94]$, post-translational modifications (phosphorylation) [33,35,95], divalent cations [31,32], crowding conditions [25], presence of target protein [25], and many others. Benesh and colleagues [90] suggested that the quaternary structure of $\alpha$-crystallins is modulated by the assembly of oligomers from monomers or from dimers and there is an exchange between these forms, that have different conformation and chaperone-like activity [90]. Aquilina and coworkers showed that the population of $\alpha \mathrm{B}$-crystallin oligomers from the bovine eye lens contains oligomers consisting of an even and odd number of subunits [96]. They concluded that a monomer is the main building block of this assembly. Considering the monomers as the most active species, one can explain why $\alpha \mathrm{B}$-crystallin can prevent protein aggregation at very low stoichiometric ratio compared to the target protein. Such effective stoichiometry is possible in the cell, since the unfolded target proteins are often present at low concentrations and aggregate slowly (for example, in the lens). Therefore, a high concentration of active monomer species is not required to prevent the unfolding and aggregation of the target protein [29].

In the present work the stoichiometry of the HSPB5-target protein complex $\left(S_{0}\right)$ have been determined for two target proteins using Equation (3). In the case of heat-induced aggregation of $\mathrm{Ph} b$ we have shown that the dependence of the $K_{\mathrm{agg}} / K_{\mathrm{agg}, 0}$ value on the ratio of molar concentrations of HSPB5 and $\mathrm{Ph} b$ ([HSPB5]/[target protein]) is complex, and the stoichiometry of the resulting chaperone-target protein complexes is variable (Figure 5). Possibly, the obtained complexity of the above dependence is associated with a change in the quaternary structure of HSPB5 with varying molar ratio [HSPB5]/[Phb]. We suggest that the rather complicated dependence of the $K_{\mathrm{agg}} / K_{\mathrm{agg}, 0}$ value on the molar ratio [HSPB5]/[Phb] (Figure 5) is associated with: (1) the change in the oligomeric state of the chaperone with an increase in its concentration, and (2) possible variations in the affinity of HSPB5 species with respect to the denatured/aggregated protein. We assume that the lower the concentration of HSPB5, the greater is the fraction of "traveling monomers" in the solution at $48^{\circ} \mathrm{C}$ [27] and, therefore, the more HSPB5 oligomers consist of monomeric building blocks [90]. With increasing concentration of HSPB5, the proportion of dimers and oligomers constructed from dimeric building blocks grows. The chaperone function of these two states is different: the monomeric substructural state has greater exposed hydrophobic surface area and is consequently more active [90]. All the above mentioned is likely to underlie the obtained value of the stoichiometry of the chaperone-target protein complexes at the initial stages of $\mathrm{Ph} b$ aggregation at $48{ }^{\circ} \mathrm{C}$ at low ratios of molar concentrations [HSPB5]/[Phb] (in the excess of the molar concentration of Phb): when one monomer of HSPB5 (with the molecular mass of $20.2 \mathrm{kDa}$ ) is complexed with over three $\mathrm{Ph} b$ monomers (with the molecular mass of $97.4 \mathrm{kDa}$ each). 
When studying the kinetics of DTT-induced aggregation of $\alpha \mathrm{La}$ (a protein with a molecular mass of the monomer of $14.2 \mathrm{kDa}$, smaller than that of HSPB5 subunit) in the presence of HSPB5 (Figure 7), we obtained an even lower value of the stoichiometry of the chaperone-target protein complexes, namely less than 0.011. The oligomeric state of HSPB5-target protein complexes was controlled by the AUC method. According to the SV analysis we conclude that suboligomeric forms of HSPB5 (monomeric or dimeric) may interact with the target protein, DTT-denatured $\alpha \mathrm{La}$, forming relatively small oligomers (see Table 1). However, the high-order oligomeric HSPB5- $\alpha$ La complexes may be present. According to Hayashi and Carver the monomeric form of HSPB5 may be its most chaperone-species active [29]. However, the presence of monomers can increase the hydrophobicity of HSPB5 and decrease its solubility. Therefore, for the chaperone-like activity, the balance between monomeric and oligomeric forms is very important.

Previously, we showed a significant effect of crowding on the oligomeric state of HSPB5 under conditions of the heat shock $\left(48^{\circ} \mathrm{C}\right)$ by the SV method [25]. It was demonstrated that, on the one hand, an elevated temperature led to the dissociation of the chaperone, and, on the other hand, crowding shifted the equilibrium toward large-sized assemblies [25]. Based on this data we assumed that the chaperone-like activity of HSPB5 is likely to be affected by the crowding.

In the present work, to quantify the effect of crowding on the chaperone-like activity of HSPB5, we selected parameter $K_{\mathrm{agg}}$ characterizing the acceleration of the aggregation process during the nucleation stage. $\mathrm{Ph} b$ aggregation at $48^{\circ} \mathrm{C}$ was chosen as a test system. Table 2 and Figure S3 show the effect of crowding on the kinetic parameters of $\mathrm{Ph} b$ thermal aggregation. When considering the effect of crowding on Ph $b$ aggregation in the presence of HSPB5, it must be emphasized that all crowders used, as well as their pairs, increase the value of parameter $K_{\text {agg }}$ as compared to that in the buffer, although to a different extent. That is, the aggregation of the target protein in the presence of HSPB5 under the conditions of crowding created by all used crowders or their mixtures is accelerated compared to the aggregation process in the buffer. Thus, the data obtained by the DLS method suppose that crowding reduces the chaperone-like activity of HSPB5.

It may be assumed that crowding accelerates the aggregation of the chaperone-target protein complexes. However, the data obtained by the SV method indicate the retention of complexes formed by the dissociated forms of HSPB5 and Ph $b$ under crowded conditions (Figures 10 and 11). This is evidenced by the disappearance of the $23 \mathrm{~S}$ peak and a decrease in the $9 \mathrm{~S}$ peak in the $c(s)$ distributions corresponding to the sedimentation of individual HSPB5 and $\mathrm{Ph} b$, respectively, and the appearance of peaks with $s_{20, \mathrm{w}}$ values of 11, 14, $16 \mathrm{~S}$ for HSPB5-Phb mixture under crowded conditions arising from the presence of the pair of crowders, $\mathrm{PVP}_{25 \mathrm{kDa}}+\mathrm{PEG}_{20 \mathrm{kDa}}$ (Figure 11). That is, under mixed crowding conditions, although a 55 -fold increase in the value of parameter $K_{\text {agg }}$ was registered by DLS (compared with the buffer, Table 2), complexes formed by the suboligomeric forms of HSPB5 with the target protein are retained in the solution. This fact is consistent with our earlier data on the interaction of HSPB5 with $\mathrm{Ph} b$ at $48^{\circ} \mathrm{C}$ in the presence of the pair of crowders, $\mathrm{PEG}_{20 \mathrm{kDa}}$ and TMAO [25]. The presence of a target protein may stimulate the dissociation of large HSPB5 assemblies. However, the existence of high-order oligomeric HSPB5-Phb complexes cannot be ruled out. The obtained results support our previous data on the formation of the complexes between dissociated forms of bovine lens $\alpha$-crystallin and an apoform of $\mathrm{Ph} b$ [63], or $\mathrm{Ph} b$ denatured by ultraviolet radiation [62], apart from the high order complexes. The presence of two types of complexes formed by $\alpha$-crystallin and target proteins, which differ in their sensitivity to crowding and aggregation, was reported in the work [62]. High molecular mass complexes are aggregation-prone, whereas complexes formed by small suboligomeric forms of chaperone with a target protein are more resistant to aggregation under crowding conditions [36,62]. We suggested that these small complexes are responsible for the realization of the chaperone-like activity of HSPB5 or $\alpha$-crystallin under crowded conditions [25,36,62]. Our results are consistent with this idea.

Thus, we showed that by changing the combination of different crowding agents, almost spherical crowders, like Ficoll, or linear polymers, like PVP, it is possible to regulate (moderate) the activity 
of the chaperone. Our studies show that adding even one crowder to an existing one dramatically changes the effectiveness of the crowding. Parameter $K_{\text {agg }}$ increases in 13.7-55 times in the presence of those pairs of crowders that exhibit synergism (Table 2). On the one hand, this can be explained by the increase (strengthening) of the excluded volume effect, which leads to acceleration of the target protein aggregation. On the other hand, it is currently believed that, in addition to the excluded volume effect (steric repulsion of macromolecules - the entropy factor), the forces of weak interaction between protein molecules and crowder molecules (enthalpy factor) play a significant role in crowded environment [49,50,97-100]. In addition, biopolymers (proteins) capable of reversibly changing the state of association/dissociation or accepting an expanded or compact state of the quaternary structure can change the level of excluded volume in cells [101,102]. It is assumed that proteins with such properties, through their ability to directly influence the degree of excluded volume, will dynamically regulate the functions of proteins in biological media [102]. Small heat shock proteins, such as HSPB5, can take extended or compact states $[9,20]$ and change the state of association, therefore may affect the effective level of excluded volume. Thus, crowding adds another level of complexity to the relationship between the activity and structural dynamics of sHSPs.

An increase in the concentration of sHSPs and their activity during a stress play a protective role in the cell, but there are situations when the activity of the chaperone should be reduced, for example, in cancer cells. Crowding should be considered as one of the factors that may subtly modulate sHSPs activity.

\section{Materials and Methods}

\subsection{Materials}

$\mathrm{Ca}^{2+}$-depleted $\alpha$-lactalbumin $(\alpha \mathrm{La})$, mono- and dibasic sodium phosphates, Hepes, ethylenediaminetetraacetic acid (EDTA), Ficoll with a molecular mass of 70,000 Da (Ficoll $70 \mathrm{kDa}$ ), polyvinylpyrrolidone (PVP) with a molecular mass of 10,000 Da ( $\left.\mathrm{PVP}_{10 \mathrm{kDa}}\right)$ and $25,000-30,000 \mathrm{Da}$ $\left(\mathrm{PVP}_{25 \mathrm{kDa}}\right)$ were purchased from Sigma-Aldrich (St. Louis, MO, USA). 1,4-dithiothreitol (DTT) was purchased from PanReac (Barcelona, Spain). Polyethylene glycol (PEG) with a molecular mass of 20,000 Da ( $\mathrm{PEG}_{20 \mathrm{kDa}}$ ) was purchased from Ferak Berlin (Berlin, Germany). $\mathrm{NaCl}$ was purchased from Reakhim (Moscow, Russia). All solutions for the experiments were prepared using deionized milli-Q quality water obtained with the Easy-Pure II RF system (Thermo Fisher Scientific, Barnstead, city, NH, USA). The procedure of isolation of glycogen phosphorylase $b$ (Ph $b$, Uniprot IDP00489) from rabbit skeletal muscles was described in the work [103]. Human full-length untagged HSPB5 (Uniprot ID P02511) was expressed and purified as described earlier [104] and stored frozen at $-20{ }^{\circ} \mathrm{C}$. Size-exclusion chromatography elution profile of HSPB5 on a Superdex 200 column and SDS-gel electrophoresis of the stock HSPB5 sample and its SEC elution fractions are presented in Figure S4. The authors thank Nikolai Sluchanko for a gift of the HSPB5 preparation and its characteristics.

The $\alpha$ La solutions were prepared by dissolving the desired amount of lyophilized protein powder in $0.1 \mathrm{M}$ Na-phosphate buffer, $\mathrm{pH}$ 6.8. Before DLS measurements the solutions were centrifuged at $20,000 \times \mathrm{g}$ and $+4{ }^{\circ} \mathrm{C}$ for $30 \mathrm{~min}$ to clear them from insoluble particles. Stock Phb and HSPB5 solutions were centrifuged at $12,850 \times g$ and $+4{ }^{\circ} \mathrm{C}$ for $10 \mathrm{~min}$ after the dialysis against $30 \mathrm{mM}$ Hepes buffer, $\mathrm{pH}$ 6.8, containing $0.1 \mathrm{M} \mathrm{NaCl}, 0.2 \mathrm{mM}$ EDTA. Protein concentrations were determined using a Nanophotometer P330 (Implen $\mathrm{GmbH}$, Munich city, Germany) with the extinction coefficient $\varepsilon_{280}^{0.1 \%}$ equal to 1.32 for Phb [105], 0.693 for HSPB5 [104] and 2.01 for $\alpha$ La [106].

\subsection{Dynamic Light Scattering (DLS)}

Aggregation of the proteins under the study was monitored by changes in the light scattering intensity at $90^{\circ}$ angle. The light scattering kinetic curves were registered by Photocor Complex correlation spectrophotometer (PhotoCor Instruments, Inc., College Park, MD, USA) with a He-Ne 
laser (Coherent Inc., Santa Clara, CA, USA, Model 31-2082, $632.8 \mathrm{~nm}, 10 \mathrm{~mW}$ ) as a light source. All experiments were repeated at least three times.

The kinetics of thermal aggregation of $\mathrm{Ph} b$ in the absence and in the presence of HSPB5 was studied both in dilute (30 mM Hepes buffer, $\mathrm{pH} 6.8$, containing $0.1 \mathrm{M} \mathrm{NaCl}, 0.2 \mathrm{mM}$ EDTA) and crowded solutions (the same buffer with the addition of Ficoll $70 \mathrm{kDa}, \mathrm{PEG}_{20 \mathrm{kDa}}, \mathrm{PVP}_{10 \mathrm{kDa}}, \mathrm{PVP}_{25 \mathrm{kDa}}$, or mixtures of these crowding agents) at $48^{\circ} \mathrm{C}$. All solutions were prepared on the buffer passed through a $20 \mathrm{~nm}$ "Anotop" filter (Whatman, Cytiva, Little Chalfont, Buckinghamshire, UK). The aggregation process was initiated by the addition of an aliquot of $\mathrm{Ph} b$ to the solution (lacking/containing HSPB5 and/or crowding agents) pre-incubated at $48^{\circ} \mathrm{C}$. The final volume of the probe was $0.5 \mathrm{~mL}$. Cells with a stopper were used to avoid evaporation during the experiment. The diffusion coefficient $(D)$, measured at $48 \mathrm{C}$, were estimated based on 5 independent measurements.

It should be noted that the absolute values of the parameters $K_{\mathrm{agg}}$ and $t_{0}$ calculated from Equation (1) may vary in the sets of experiments conducted with protein samples of different extractions (owing to circumstances beyond our control). The experience of our many years of work with $\mathrm{Ph} b$ shows that the preparation of freshly isolated $\mathrm{Ph} b$ is relatively stable for about two weeks after isolation. Nevertheless, the properties of $\mathrm{Ph} b$ (kinetic parameters of the enzymatic reaction, thermal stability, oligomeric state and other properties) undergo small changes during about two weeks after isolation. This means that each series of experiments is being carried out for one day and the necessary comparisons can be made within this series.

To register the kinetic curves of DTT-induced $\alpha$ La aggregation in the absence and in the presence of HSPB5, the aliquots of the chaperone and $\alpha$ La were placed in a buffer solution $(0.1 \mathrm{M}$ Na-phosphate buffer, $\mathrm{pH}$ 6.8) pre-heated at $37^{\circ} \mathrm{C}$ to obtain the desired final concentrations. The aggregation process was initiated by the addition of DTT to the final concentration of $20 \mathrm{mM}$.

DynaLS software (Alango, Tirat Carmel, Israel) was used for polydisperse analysis of DLS data. The values of the refractive index and the dynamic viscosity of the solutions used in the DLS measurements at $48{ }^{\circ} \mathrm{C}$ are presented in Table S1 of the Supplementary Materials.

\subsection{Analytical Ultracentrifugation (AUC)}

Sedimentation velocity (SV) experiments were carried out using a Model E analytical ultracentrifuge (Beckman Instruments, Palo Alto, CA, USA) equipped with absorbance optics, a photoelectric scanner, a monochromator and a computer on-line. In the case of $\mathrm{Ph} b \mathrm{SV}$ runs were performed in $30 \mathrm{mM}$ Hepes buffer, pH 6.8, containing $0.1 \mathrm{M} \mathrm{NaCl}, 0.2 \mathrm{mM}$ EDTA, with or without different crowding agents at $48{ }^{\circ} \mathrm{C}$. Before the experiment, all samples were incubated for $40 \mathrm{~min}$ at $48^{\circ} \mathrm{C}$. A four-hole rotor An-F Ti and 12-mm double sector cells were used. Before the run, the rotor was pre-heated in a thermostat at $48{ }^{\circ} \mathrm{C}$ overnight. In the case of $\alpha \mathrm{La}$, SV runs were performed in $0.1 \mathrm{M}$ Na-phosphate buffer, $\mathrm{pH} 6.8$, containing $10 \mathrm{mM} \mathrm{NaCl}$ and $20 \mathrm{mM}$ DTT, at $37^{\circ} \mathrm{C}$. Before the run, the rotor An-F Ti was pre-heated in a thermostat at $37^{\circ} \mathrm{C}$ overnight. Sedimentation profiles were recorded by measuring the absorbance at $280 \mathrm{~nm}$. All cells were scanned simultaneously. The time interval between scans was $2.5 \mathrm{~min}$. The differential sedimentation coefficient distributions $[c(s)$ versus s] were determined using SEDFIT program [107]. Sedimentation coefficients were corrected to the standard conditions (a solvent with the density and viscosity of water at $20^{\circ} \mathrm{C}$ ) using SEDFIT [107]. The values of the density and the dynamic viscosity of the solutions used in the AUC measurements at $48{ }^{\circ} \mathrm{C}$ are presented in Table S1 of the Supplementary Materials.

To estimate the molecular mass of $\mathrm{Ph} b$ and possible complexes of $\mathrm{Ph} b$ with HSPB5, the Svedberg equation was used:

$$
M=s R \mathrm{~T} / D(1-v \rho),
$$

where $v$ is the partial specific volume of a protein, $\rho$ is solution density, $R$ is molar gas constant, $T$ is temperature in Kelvin, $s$ is a sedimentation coefficient, $D$ is a diffusion coefficient. For calculations we used sedimentation coefficients (s), determined by AUC, and diffusion coefficients $(D)$, determined by DLS at $48^{\circ} \mathrm{C}$. 


\subsection{Calculations}

The Origin Pro 2017 (Origin Lab Corp., Northampton, MA, USA) software was used for the calculations. The $R^{2}$ coefficient of determination was used in order to characterize the degree of agreement between the experimental data and calculated values [108].

Supplementary Materials: Supplementary materials can be found at http:/www.mdpi.com/1422-0067/21/14/4940/s1.

Author Contributions: Conceptualization B.I.K., N.A.C.; S.G.R.; V.A.B.; methodology B.I.K., N.A.C.; S.G.R.; V.A.B.; software B.I.K., N.A.C.; S.G.R.; V.A.B.; validation B.I.K.; N.A.C.; S.G.R.; V.A.B.; formal analysis N.A.C.; S.G.R.; V.A.B.; T.B.E.; V.V.M.; investigation: N.A.C.; S.G.R.; V.A.B.; V.V.M., T.B.E.; resources: N.A.C.; S.G.R.; V.A.B.; data curation B.I.K., N.A.C.; S.G.R.; V.A.B.; writing-original draft preparation N.A.C.; S.G.R.; V.A.B.; writing一review and editing B.I.K., N.A.C.; S.G.R.; visualization: B.I.K., N.A.C.; S.G.R.; V.A.B.; supervision B.I.K., project administration B.I.K., funding acquisition B.I.K., N.A.C.; S.G.R.; V.A.B.; V.V.M.; T.B.E. All authors have read and agree to the published version of the manuscript.

Funding: This work was supported by Russian Science Foundation (grant number 16-14-10055, the studies of $\mathrm{Ph} b$ aggregation) and the Ministry of Science and Higher Education of Russian Federation (the studies of $\alpha \mathrm{La}$ aggregation). The AF4 experiments were carried out on the equipment of the Shared-Access Equipment Center "Industrial Biotechnology" of Federal Research Center "Fundamentals of Biotechnology" of the Russian Academy of Sciences.

Acknowledgments: We thank N.B. Gusev and Nikolai Sluchanko for a gift of the HSPB5 preparation.

Conflicts of Interest: The authors declare no conflict of interest.

$\begin{array}{ll}\text { Abbreviations } \\ \text { ACD } & \alpha \text {-Crystalline domain } \\ \text { ATP } & \text { Adenosine triphosphate } \\ \text { AUC } & \text { Analytical ultracentrifugation } \\ \text { DLS } & \text { Dynamic light scattering } \\ \text { DTT } & \text { Dithiothreitol } \\ \text { EDTA } & \text { Ethylenediaminetetraacetic acid } \\ \text { EVE } & \text { Excluded volume effect } \\ \text { IDR } & \text { Intrinsically disordered region } \\ \text { PEG } & \text { Polyethylene glycol } \\ \text { PVP } & \text { Polyvinylpyrrolidone } \\ \text { sHSPs } & \text { Small heat shock proteins } \\ \text { SV } & \text { Sedimentation velocity }\end{array}$

\section{References}

1. Haslbeck, M.; Vierling, E.A. First line of stress defense: Small heat shock proteins and their function in protein homeostasis. J. Mol. Biol. 2015, 427, 1537-1548. [CrossRef] [PubMed]

2. Tyedmers, J.; Mogk, A.; Bukau, B. Cellular strategies for controlling protein aggregation. Nat. Rev. Mol. Cell Biol. 2010, 11, 777-788. [CrossRef] [PubMed]

3. Chen, B.; Retzlaff, M.; Roos, T.; Frydman, J. Cellular strategies of protein quality control. Cold Spring Harb. Perspect. Biol. 2011, 3, a004374. [CrossRef]

4. Mymrikov, E.V.; Seit-Nebi, A.S.; Gusev, N.B. Large potentials of small heat shock proteins. Physiol. Rev. 2011, 91, 1123-1159. [CrossRef] [PubMed]

5. Webster, J.M.; Darling, A.L.; Uversky, V.N.; Blair, L.J. Small heat shock proteins, big impact on protein aggregation in neurodegenerative disease. Front. Pharmacol. 2019, 10, 1047. [CrossRef]

6. Landsbury, A.; Perng, M.D.; Pohl, E.; Quinlan, R.A. Functional symbiosis between the intermediate filament cytoskeleton and small heat shock proteins. In Small Stress Proteins and Human Diseases; Arrigo, A.P., Simon, S., Eds.; Nova Science: New York, NY, USA, 2010; pp. 55-87.

7. Arrigo, A.P. HSP27: Novel regulator of intracellular redox state. IUBMB Life 2001, 52, 303-307. [CrossRef]

8. Basha, E.; O’Neill, H.; Vierling, E. Small heat shock proteins and $\alpha$-crystallins: Dynamic proteins with flexible functions. Trends Biochem. Sci. 2012, 37, 106-117. [CrossRef] 
9. Hilton, G.R.; Lioe, H.; Stengel, F.; Baldwin, A.J.; Benesch, J.L.P. Small heat-shock proteins: Paramedics of the cell. In Molecular Chaperones. Topics in Current Chemistry; Jackson, S., Ed.; Springer: Berlin/Heidelberg, Germany, 2013; Volume 328, pp. 69-98. [CrossRef]

10. Carra, S.; Alberti, S.; Benesch, J.L.P.; Boelens, W.; Buchner, J.; Carver, J.A.; Cecconi, C.; Ecroyd, H.; Gusev, N.B.; Hightower, L.E.; et al. Small heat shock proteins: Multifaceted proteins with important implications for life. Cell Stress Chaperones 2019, 24, 295-308. [CrossRef]

11. Ciocca, D.R.; Calderwood, S.K. Heat shock proteins in cancer: Diagnostic, prognostic, predictive, and treatment implications. Cell Stress Chaperones 2005, 10, 86-103. [CrossRef]

12. Clark, A.R.; Lubsen, N.H.; Slingsby, C. sHSP in the eye lens: Crystallin mutations, cataract and proteostasis. Int. J. Biochem. Cell Biol. 2012, 44, 1687-1697. [CrossRef] [PubMed]

13. Makley, L.N.; McMenimen, K.A.; DeVree, B.T.; Goldman, J.W.; McGlasson, B.N.; Rajagopal, P.; Dunyak, B.M.; McQuade, T.J.; Thompson, A.D.; Sunahara, R.; et al. Pharmacological chaperone for $\alpha$-crystallin partially restores transparency in cataract models. Science 2015, 350, 674-677. [CrossRef] [PubMed]

14. Gerasimovich, E.S.; Strelkov, S.V.; Gusev, N.B. Some properties of three $\alpha$ B-crystallin mutants carrying point substitutions in the C-terminal domain and associated with congenital diseases. Biochimie 2017, 142, 168-178. [CrossRef] [PubMed]

15. Nefedova, V.V.; Muranova, L.K.; Sudnitsyna, M.V.; Ryzhavskaya, A.S.; Gusev, N.B. Small heat shock proteins and distal hereditary neuropathies. Biochemistry 2015, 80, 1734-1747. [CrossRef] [PubMed]

16. Ryazantsev, S.N.; Poliansky, N.B.; Chebotareva, N.A.; Muranov, O.K. 3D structure of the native $\alpha$-crystallin from bovine eye lens. Int. J. Biol. Macromol. 2018, 117, 1289-1298. [CrossRef] [PubMed]

17. Delaye, M.; Tardieu, A. Short-range order of crystallin proteins accounts for eye lens transparency. Nature 1983, 302, 415-417. [CrossRef] [PubMed]

18. Sudnitsyna, M.V.; Mymrikov, E.V.; Seit-Nebi, A.S.; Gusev, N.B. The role of intrinsically disordered regions in the structure and functioning of small heat shock proteins. Curr. Protein Pept. Sci. 2012, 13, 76-85. [CrossRef]

19. Delbecq, C.P.; Klevit, R.E. One size does not fit all: The oligomeric states of $\alpha$ B crystallin. FEBS Lett. 2013, 587, 1073-1080. [CrossRef]

20. Carver, J.A.; Grosas, A.B.; Ecroyd, H.; Quinlan, R.A. The functional roles of the unstructured N- and C-terminal regions in $\alpha \mathrm{B}$-crystallin and other mammalian small heat-shock proteins. Cell Stress Chaperones 2017, 22, 627-638. [CrossRef]

21. Peschek, J.; Braun, N.; Rohrberg, J.; Back, K.C.; Kriehuber, T.; Kastenmuller, A.; Weinkauf, S.; Buchner, J. Regulated structural transitions unleash the chaperone activity of $\alpha \mathrm{B}$-crystallin. Proc. Natl. Acad. Sci. USA 2013, 110, E3780-E3789. [CrossRef]

22. Hochberg, G.K.A.; Shepherd, D.A.; Marklund, E.G.; Santhanagoplan, I.; Degiacomi, M.T.; Laganowsky, A.; Allison, T.M.; Basha, E.; Marty, M.T.; Galpin, M.R.; et al. Structural principles that enable oligomeric small heat shock protein paralogs to evolve distinct functions. Science 2018, 359, 930-935. [CrossRef]

23. Hochberg, G.K.A.; Benesch, J.L.P. Dynamical structure of $\alpha$ B-crystallin. Prog. Biophys. Mol. Biol. 2014, 115, 11-20. [CrossRef] [PubMed]

24. Braun, N.; Zacharias, M.; Peschek, J.; Kastenmuller, A.; Zou, J.; Hanzlik, M.; Haslbeck, M.; Rappsilber, J.; Buchner, J.; Weinkauf, S. Multiple molecular architectures of the eye lens chaperone $\alpha \mathrm{B}$-crystallin elucidated by a triple hybrid approach. Proc. Natl. Acad. Sci. USA 2011, 108, 20491-20496. [CrossRef] [PubMed]

25. Chebotareva, N.A.; Eronina, T.B.; Roman, S.G.; Mikhaylova, V.V.; Sluchanko, N.N.; Gusev, N.B.; Kurganov, B.I. Oligomeric state of $\alpha \mathrm{B}$-crystallin under crowded conditions. Biochem. Biophys. Res. Commun. 2019, 508, 1101-1105. [CrossRef]

26. Mchaourab, H.S.; Godar, J.A.; Stewart, P.L. Structure and mechanism of protein stability sensors: The chaperone activity of small heat-shock proteins. Biochemistry 2009, 48, 3828-3837. [CrossRef] [PubMed]

27. Inoue, R.; Takata, T.; Fujii, N.; Ishii, K.; Uchiyama, S.; Sato, N.; Oba, Y.; Wood, K.; Kato, K.; Fujii, N.; et al. New insight into the dynamical system of $\alpha$ B-crystallin oligomers. Sci. Rep. 2016, 6, 29208. [CrossRef]

28. Stengel, F.; Baldwin, A.J.; Painter, A.J.; Jaya, N.; Basha, E.; Kay, L.E.; Vierling, E.; Robinson, C.V.; Benesch, J.L.P. Quaternary dynamics and plasticity underlie small heat shock protein chaperone function. Proc. Natl. Acad. Sci. USA 2010, 107, 2007-2012. [CrossRef]

29. Hayashi, J.; Carver, J.A. The multifaceted nature of $\alpha$ B-crystallin. Cell Stress Chaperones 2020, 25, 639-654. [CrossRef] 
30. Alderson, T.R.; Roche, J.; Gastall, H.Y.; Dias, D.M.; Pritišanac, I.; Ying, J.; Bax, A.; Benesch, J.L.P.; Baldwin, A.J. Local unfolding of the HSP27 monomer regulates chaperone activity. Nat. Commun. 2019, 10, 1068. [CrossRef]

31. Liu, L.; Ghosh, J.G.; Clark, J.I.; Jiang, S. Studies of $\alpha$ B-crystallin subunit dynamics by surface plasmon resonance. Anal. Biochem. 2006, 350, 186-195. [CrossRef]

32. Chebotareva, N.A.; Eronina, T.B.; Sluchanko, N.N.; Kurganov, B.I. Effect of $\mathrm{Ca}^{2+}$ and $\mathrm{Mg}^{2+}$ ions on oligomeric state and chaperone-like activity of $\alpha$ B-crystallin in crowded media. Int. J. Biol. Macromol. 2015, 76, 86-93. [CrossRef]

33. Ecroyd, H.; Meehan, S.; Horwitz, J.; Aquilina, J.A.; Benesch, J.L.; Robinson, C.V.; Macphee, C.E.; Carver, J.A. Mimicking phosphorylation of $\alpha$ B-crystallin affects its chaperone activity. Biochem. J. 2007, 401, 129-141. [CrossRef]

34. Jovcevski, B.; Kelly, M.A.; Rote, A.P.; Berg, T.; Gastall, H.Y.; Benesch, J.L.P.; Aquilina, J.A.; Ecroyd, H. Phosphomimics destabilize Hsp27 oligomeric assemblies and enhance chaperone activity. Chem. Biol. 2015, 22, 186-195. [CrossRef]

35. Muranova, L.K.; Sudnitsyna, M.V.; Gusev, N.B. $\alpha$ B-Crystallin phosphorylation: Advances and problems. Biochemistry 2018, 83, 1196-1206. [CrossRef] [PubMed]

36. Roman, S.G.; Chebotareva, N.A.; Kurganov, B.I. Anti-aggregation activity of small heat shock proteins under crowded conditions. Int. J. Biol. Macromol. 2017, 100, 97-103. [CrossRef]

37. Fonin, A.V.; Darling, A.L.; Kuznetsova, I.M.; Turoverov, K.K.; Uversky, V.N. Intrinsically disordered proteins in crowded milieu: When chaos prevails within the cellular gumbo. Cell. Mol. Life Sci. 2018, 75, 3907-3929. [CrossRef]

38. Kuznetsova, I.M.; Turoverov, K.K.; Uversky, V.N. What macromolecular crowding can do to a protein. Int. J. Mol. Sci. 2014, 15, 23090-23140. [CrossRef] [PubMed]

39. $\mathrm{Fu}, \mathrm{X}$. Insights into how small heat shock proteins bind a great diversity of substrate proteins: A super-transformer model. In The Big Book on Small Heat Shock Proteins; Tanguay, R.M., Hightower, L.E., Eds.; Springer: Cham, Switzerland, 2015; pp. 101-117. [CrossRef]

40. Zimmerman, S.B.; Trach, S.O. Estimation of macromolecule concentrations and excluded volume effects for the cytoplasm of Escherichia coli. J. Mol. Biol. 1991, 222, 599-620. [CrossRef]

41. Zimmerman, S.B.; Minton, A.P. Macromolecular crowding: Biochemical, biophysical, and physiological consequences. Annu. Rev. Biophys. Biomol. Struct. 1993, 22, 23-65. [CrossRef]

42. Ellis, R.J. Macromolecular crowding: Obvious but underappreciated. Trends Biochem. Sci. 2001, 26, 597-604. [CrossRef]

43. Minton, A.P. The influence of macromolecular crowding and macromolecular confinement on biochemical reactions in physiological media. J. Biol. Chem. 2001, 276, 10577-10580. [CrossRef]

44. Minton, A.P.; Wilf, J. Effect of macromolecular crowding upon the structure and function of an enzyme: Glyceraldehyde-3-phosphate dehydrogenase. Biochemistry 1981, 20, 4821-4826. [CrossRef] [PubMed]

45. Chebotareva, N.A.; Kurganov, B.I.; Livanova, N.B. Biochemical effects of molecular crowding. Biochemistry 2004, 69, 1239-1251. [CrossRef]

46. Ellis, R.J.; Minton, A.P. Protein aggregation in crowded environments. Biol. Chem. 2006, 387, 485-497. [CrossRef] [PubMed]

47. Zhou, H.X.; Rivas, G.; Minton, A.P. Macromolecular crowding and confinement: Biochemical, biophysical, and potential physiological consequences. Annu. Rev. Biophys. 2008, 37, 375-397. [CrossRef] [PubMed]

48. Ellis, R.J. Protein aggregation: Opposing effects of chaperones and crowding. In Folding for the Synapse; Wyttenbach, A., O'Connor, V., Eds.; Springer: Boston, MA, USA, 2011; pp. 9-34.

49. Dewavrin, I.-Y.; Abdurrahiem, M.; Blocki, A.; Musib, M.; Piazza, F.; Raghunath, M. Synergistic rate of collagen fibrillogenesis in heterogeneous mixture of crowding agents. J. Phys. Chem. B 2015, 119, 4350-4358. [CrossRef]

50. Shah, D.; Tan, A.L.; Ramakrishnan, V.; Jiang, J.; Rajagopalan, R. Effects of polydisperse crowders on aggregation reactions: A molecular thermodynamic analysis. J. Chem. Phys. 2011, 134, 064704. [CrossRef]

51. Du, F.; Zhou, Z.; Mo, Z.-Y.; Shi, J.-Z.; Chen, J.; Liang, Y. Mixed macromolecular crowding accelerates the refolding of rabbit muscle creatine kinase: Implications for protein folding in physiological environments. J. Mol. Biol. 2006, 364, 469-482. [CrossRef]

52. Batra, J.; Xu, K.; Zhou, H.-X. Nonadditive effects of mixed crowding on protein stability. Proteins 2009, 77, 133-138. [CrossRef] 
53. Phillip, Y.; Schreiber, G. Formation of protein complexes in crowded environments-From in vitro to in vivo. FEBS Lett. 2013, 587, 1046-1052. [CrossRef]

54. Nakano, S.; Miyoshi, D.; Sugimoto, N. Effects of molecular crowding on the structures, interactions, and functions of nucleic acids. Chem. Rev. 2014, 114, 2733-2758. [CrossRef]

55. Sarkar, M.; Smith, A.E.; Pielak, G.J. Impact of reconstituted cytosol on protein stability. Proc. Natl. Acad. Sci. USA 2013, 110, 19342-19347. [CrossRef] [PubMed]

56. Mittal, S.; Chowhan, R.K.; Singh, L.R. Macromolecular crowding: Macromolecules friend or foe. Biochim. Biophys. Acta 2015, 1850, 1822-1831. [CrossRef]

57. Stepanenko, O.V.; Povarova, O.I.; Sulatskaya, A.I.; Ferreira, L.A.; Zaslavsky, B.Y.; Kuznetsova, I.M.; Turoverov, K.K.; Uversky, V.N. Protein unfolding in crowded milieu: What crowding can do to a protein undergoing unfolding? J. Biomol. Struct. Dyn. 2016, 34, 2155-2170. [CrossRef]

58. Shahid, S.; Hassan, M.I.; Islam, A.; Ahmad, F. Size-dependent studies of macromolecular crowding on the thermodynamic stability, structure and functional activity of proteins: In vitro and in silico approaches. Biochim. Biophys. Acta, Gen. Subj. 2017, 1861, 178-197. [CrossRef] [PubMed]

59. Shahid, S.; Ahmad, F.; Hassan, M.I.; Islam, A. Relationship between protein stability and functional activity in the presence of macromolecular crowding agents alone and in mixture: An insight into stability-activity trade-off. Arch. Biochem. Biophys. 2015, 584, 42-50. [CrossRef] [PubMed]

60. Sharp, K.A. Analysis of the size dependence of macromolecular crowding shows that smaller is better. Proc. Natl. Acad. Sci. USA 2015, 112, 7990-7995. [CrossRef] [PubMed]

61. Chebotareva, N.A.; Makeeva, V.F.; Bazhina, S.G.; Eronina, T.B.; Gusev, N.B.; Kurganov, B.I. Interaction of Hsp27 with native phosphorylase kinase under crowding conditions. Macromol. Biosci. 2010, 10, 783-789. [CrossRef]

62. Roman, S.G.; Chebotareva, N.A.; Eronina, T.B.; Kleymenov, S.Y.; Makeeva, V.F.; Poliansky, N.B.; Muranov, K.O.; Kurganov, B.I. Does the crowded cell-like environment reduce the chaperone-like activity of $\alpha$-crystallin? Biochemistry 2011, 50, 10607-10623. [CrossRef]

63. Chebotareva, N.A.; Eronina, T.B.; Roman, S.G.; Poliansky, N.B.; Muranov, K.O.; Kurganov, B.I. Effect of crowding and chaperones on self-association, aggregation and reconstitution of apophosphorylase $b$. Int. J. Biol. Macromol. 2013, 60, 69-76. [CrossRef]

64. Sluchanko, N.N.; Chebotareva, N.A.; Gusev, N.B. Quaternary structure of human small heat shock protein HSPB6 (Hsp20) in crowded media modeled by trimethylamine N-oxide (TMAO): Effect of protein phosphorylation. Biochimie 2015, 108, 68-75. [CrossRef]

65. Eronina, T.B.; Mikhaylova, V.V.; Chebotareva, N.A.; Kurganov, B.I. Kinetic regime of thermal aggregation of holo- and apoglycogen phosphorylases b. Int. J. Biol. Macromol. 2016, 92, 1252-1257. [CrossRef] [PubMed]

66. Bumagina, Z.M.; Gurvits, B.Y.; Artemova, N.V.; Muranov, K.O.; Yudin, I.K.; Kurganov, B.I. Mechanism of suppression of dithiothreitol-induced aggregation of bovine $\alpha$-lactalbumin by $\alpha$-crystallin. Biophys. Chem. 2010, 146, 108-117. [CrossRef] [PubMed]

67. Borzova, V.A.; Markossian, K.A.; Kurganov, B.I. Relationship between the initial rate of protein aggregation and the lag period for amorphous aggregation. Int. J. Biol. Macromol. 2014, 68, 144-150. [CrossRef] [PubMed]

68. Chebotareva, N.A.; Filippov, D.O.; Kurganov, B.I. Effect of crowding on several stages of protein aggregation in test systems in the presence of $\alpha$-crystallin. Int. J. Biol. Macromol. 2015, 80, 358-365. [CrossRef] [PubMed]

69. Barford, D.; Johnson, L.N. The allosteric transition of glycogen phosphorylase. Nature 1989, 340, 609-616. [CrossRef]

70. Permyakov, E.A.; Berliner, L.J. $\alpha$-Lactalbumin: Structure and function. FEBS Lett. 2000, 473, $269-274$. [CrossRef]

71. Kuwajima, K. The molten globule state of $\alpha$-lactalbumin. FASEB J. 1996, 10, 102-109. [CrossRef]

72. Kulig, M.; Ecroyd, H. The small heat-shock protein $\alpha$ B-crystallin uses different mechanisms of chaperone action to prevent the amorphous versus fibrillar aggregation of $\alpha$-lactalbumin. Biochem. J. 2012, 448, 343-352. [CrossRef]

73. Carver, J.A.; Lindner, R.A.; Lyon, C.; Canet, D.; Hernandez, H.; Dobson, C.M.; Redfield, C. The interaction of the molecular chaperone $\alpha$-crystallin with unfolding $\alpha$-lactalbumin: A structural and kinetic spectroscopic study. J. Mol. Biol. 2002, 318, 815-827. [CrossRef] 
74. Lindner, R.A.; Treweek, T.M.; Carver, J.A. The molecular chaperone $\alpha$-crystallin is in kinetic competition with aggregation to stabilize a monomeric molten-globule form of $\alpha$-lactalbumin. Biochem. J. 2001, 354, $79-87$. [CrossRef]

75. Ecroyd, H.; Carver, J.A. The effect of small molecules in modulating the chaperone activity of $\alpha \mathrm{B}$-crystallin against ordered and disordered protein aggregation. FEBS J. 2008, 275, 935-947. [CrossRef] [PubMed]

76. Sanders, H.M.; Jovcevski, B.; Carver, J.A.; Pukala, T.L. The molecular chaperone $\beta$-casein prevents amorphous and fibrillar aggregation of $\alpha$-lactalbumin by stabilization of dynamic disorder. Biochem. J. 2020, 477, 629-643. [CrossRef] [PubMed]

77. Patro, S.Y.; Przybycien, T.M. Simulations of reversible protein aggregate and crystal structure. Biophys. J. 1996, 70, 2888-2902. [CrossRef]

78. Ferrone, F. Analysis of protein aggregation kinetics. Methods Enzymol. 1999, 309, 256-274. [CrossRef]

79. Powers, E.T.; Ferrone, F.A. Kinetic models for protein misfolding and association. In Protein Misfolding Diseases: Current and Emerging Principles and Therapies; Ramirez-Alvarado, M., Kelly, J.W., Dobson, C.M., Eds.; John Wiley \& Sons, Inc.: Hoboken, NJ, USA, 2010; pp. 73-92.

80. Hirota, N.; Edskes, H.; Hall, D. Unified theoretical description of the kinetics of protein aggregation. Biophys. Rev. 2019, 11, 191-208. [CrossRef]

81. Chen, S.; Ferrone, F.A.; Wetzel, R. Huntington's disease age-of-onset linked to polyglutamine aggregation nucleation. Proc. Natl. Acad. Sci. USA 2002, 99, 11884-11889. [CrossRef]

82. Kurganov, B.I. Kinetics of heat aggregation of proteins. Biochemistry 1998, 63, 364-366. [PubMed]

83. Kurganov, B.I. Antiaggregation activity of chaperones and its quantification. Biochemistry 2013, 78, 1554-1566. [CrossRef]

84. Kurganov, B.I. Quantification of anti-aggregation activity of chaperones. Int. J. Biol. Macromol. 2017, 100, 104-117. [CrossRef]

85. Golub, N.; Meremyanin, A.; Markossian, K.; Eronina, T.; Chebotareva, N.; Asryants, R.; Muronets, V.; Kurganov, B. Evidence for the formation of start aggregates as an initial stage of protein aggregation. FEBS Lett. 2007, 581, 4223-4227. [CrossRef]

86. Khanova, H.A.; Markossian, K.A.; Kurganov, B.I.; Samoilov, A.M.; Kleimenov, S.Y.; Levitsky, D.I.; Yudin, I.K.; Timofeeva, A.C.; Muranov, K.O.; Ostrovsky, M.A. Mechanism of chaperone-like activity. Suppression of thermal aggregation of $\beta_{\mathrm{L}}$-crystallin by $\alpha$-crystallin. Biochemistry 2005, 44, 15480-15487. [CrossRef]

87. Golub, N.V.; Markossian, K.A.; Kasilovich, N.V.; Sholukh, M.V.; Orlov, V.N.; Kurganov, B.I. Thermal inactivation, denaturation and aggregation of mitochondrial aspartate aminotransferase. Biophys. Chem. 2008, 135, 125-131. [CrossRef]

88. Eronina, T.B.; Chebotareva, N.A.; Roman, S.G.; Kleymenov, S.Y.; Makeeva, V.F.; Polansky, N.B.; Muranov, K.O.; Kurganov, B.I. Thermal denaturation and aggregation of apoform of glycogen phosphorylase $b$. Effect of crowding agents and chaperones. Biopolymers 2014, 101, 504-516. [CrossRef] [PubMed]

89. Borzova, V.A.; Markossian, K.A.; Kara, D.A.; Chebotareva, N.A.; Makeeva, V.F.; Poliansky, N.B.; Muranov, K.O.; Kurganov, B.I. Quantification of anti-aggregation activity of chaperones: A test-system based on dithiothreitol-induced aggregation of bovine serum albumin. PLoS ONE 2013, 8, e74367. [CrossRef] [PubMed]

90. Benesch, J.L.P.; Ayoub, M.; Robinson, C.V.; Aquilina, J.A. Small heat shock protein activity is regulated by variable oligomeric substructure. J. Biol. Chem. 2008, 283, 28513-28517. [CrossRef] [PubMed]

91. Haslbeck, M.; Peschek, J.; Buchner, J.; Weinkauf, S. Structure and function of $\alpha$-crystallins: Traversing from in vitro to in vivo. Biochim. Biophys. Acta 2016, 1860, 159-166. [CrossRef] [PubMed]

92. Bova, M.; Ding, L.-L.; Horwitz, J.; Fung, B.K.-K. Subunit exchange of $\alpha$ A-crystallin. J. Biol. Chem. 1997, 272, 29511-29517. [CrossRef]

93. Abgar, S.; Backmann, J.; Aerts, T.; Vanhoudt, J.; Clauwaert, J. The structural differences between bovine lens $\alpha \mathrm{A}$ - and $\alpha \mathrm{B}$-crystallin. Eur. J. Biochem. 2000, 267, 5916-5925. [CrossRef]

94. Vanhoudt, J.; Abgar, S.; Aerts, T.; Clauwaert, J. Native quaternary structure of bovine $\alpha$-crystallin. Biochemistry 2000, 39, 4483-4492. [CrossRef]

95. Bakthisaran, R.; Akula, K.K.; Tangirala, R.; Rao, C.M. Phosphorylation of $\alpha$ B-crystallin: Role in stress, aging and pathophysiological conditions. Biochim. Biophys. Acta Gen. Subj. 2016, 1860, 167-182. [CrossRef] 
96. Aquilina, J.A.; Benesch, J.L.P.; Bateman, O.A.; Slingsby, C.; Robinson, C.V. Polydispersity of a mammalian chaperone: Mass spectrometry reveals the population of oligomers in $\alpha$ B-crystallin. Proc. Natl. Acad. Sci. USA 2003, 100, 10611-10616. [CrossRef] [PubMed]

97. Hu, Z.; Jiang, J.; Rajagopalan, R. Effects of macromolecular crowding on biochemical reaction equilibria: A molecular thermodynamic perspective. Biophys. J. 2007, 93, 1464-1473. [CrossRef] [PubMed]

98. Schlesinger, A.P.; Wang, Y.; Tadeo, X.; Millet, O.; Pielak, G.J. Macromolecular crowding fails to fold a globular protein in cell. J. Am. Chem. Soc. 2011, 133, 8082-8085. [CrossRef] [PubMed]

99. Sukenik, S.; Harries, D. Balance of enthalpy and entropy in depletion forces. Curr. Opin. Colloid Interface Sci. 2013, 18, 495-501. [CrossRef]

100. Mukherjee, S.K.; Gautam, S.; Biswas, S.; Kundu, J.; Chowdhury, P.K. Do macromolecular crowding agents exert only an excluded volume effect? A protein solvation study. J. Phys. Chem. B 2015, 119, 14145-14156. [CrossRef] [PubMed]

101. Hall, D. Protein self-association in the cell: A mechanism for fine tuning the level of macromolecular crowding? Eur. Biophys. J. 2006, 35, 276-280. [CrossRef]

102. Hall, D.; Dobson, C.M. Expanding to fill the gap: A possible role for inert biopolymers in regulating the extent of the "macromolecular crowding" effect. FEBS Lett. 2006, 580, 2584-2590. [CrossRef]

103. Eronina, T.B.; Chebotareva, N.A.; Roman, S.G.; Makeeva, V.F.; Kleymenov, S.Y.; Kurganov, B.I. Effect of proline on thermal inactivation, denaturation and aggregation of glycogen phosphorylase $b$ from rabbit skeletal muscle. Biophys. Chem. 2009, 141, 66-74. [CrossRef]

104. Mymrikov, E.V.; Bukach, O.V.; Seit-Nebi, A.S.; Gusev, N.B. The pivotal role of the $\beta 7$ strand in the intersubunit contacts of different human small heat shock proteins. Cell Stress Chaperones 2010, 15, 365-377. [CrossRef]

105. Kastenschmidt, L.L.; Kastenschmidt, J.; Helmreich, E. Subunit interactions and their relationship to the allosteric properties of rabbit skeletal muscle phosphorylase $b$. Biochemistry 1968, 7, 3590-3608. [CrossRef]

106. Kronman, M.J.; Andreotti, R.E. Inter- and intramolecular interactions of $\alpha$-lactalbumin. I. The apparent heterogeneity at acid pH. Biochemistry 1964, 3, 1145-1151. [CrossRef] [PubMed]

107. Brown, P.H.; Schuck, P. Macromolecular size-and-shape distributions by sedimentation ultracentrifugation. Biophys. J. 2006, 90, 4651-4661. [CrossRef] [PubMed]

108. Scientist for Experimental Data Fitting. Microsoft Windows Version 2.0; MicroMath, Inc.: Salt Lake City, UT, USA, 1995. 